\title{
The Deviated Mechanisms between Chintrepreneurship and Entrepreneurship-Collectivism or Individualism in Forming the Mechanism of China-way of Entrepreneurship
}

\author{
Jiangning Zhao ${ }^{1, *}$ \\ ${ }^{1}$ College of Business Administration, Catholic University of Korea, 43 Jibong-ro, Wonmi-gu, Bucheon-si, \\ Gyeonggi-do, 420-743, South Korea \\ *Correspondence: College of Business Administration, Catholic University of Korea, 43 Jibong-ro, Wonmi-gu, \\ Bucheon-si, Gyeonggi-do, 420-743, South Korea. Tel: 86-151-6097-9098 E-mail: zjning@hotmail.com
}

Received: June 1, 2017

Accepted: July 4, 2017 Online Published: July 27, 2017

doi:10.5430/mos.v4n3p51

URL: https://doi.org/10.5430/mos.v4n3p51

\begin{abstract}
Is entrepreneurship the cause, or the consequence of economic development? Why does an economic downturn provide opportunities for entrepreneurship? How is the mechanism of entrepreneurship differentiated between developed and developing economies? How can the democracy and free-market based agent theory explain the mechanism of entrepreneurship in an autocratic and cronyism-oriented political system like China? Motivated to explore these unsettled conceptual questions, an extensive literature review and a broad range of interviews were employed as the method of this study to rationalize the formational and functional mechanism of Chintrepreneurship (China-way of Entrepreneurship) in boosting the leapfrog of China economy. This paper argues that, neither Schumpeterianism nor Keynesianism alone is able to theoretically reflect the path-dependent rise of Chintrepreneurship in today's dynamically globalized and diversified business environment. Instead, only the combination of the two camps can help rationalize the mechanism of how government intervention can act as an indispensable and irreplaceable adjustor of political-economical environment to cultivate entrepreneurship. Hence, the traditionally presumed tripartite framework (entrepreneurship, industrialization, economic growth) must be adjusted in order to offset or overcome the weakness of existing literature, and to solve the dilemmatic puzzle: which one of individualism and collectivism is more contributive to the mechanism of entrepreneurship? By defining a series of critical conditions and criteria, this paper proposes a BRIDGE model to rationalize the role of government intervention, and the observed trade-offs, such as the impact of dual-track policy on regional and wealth disparities in China. Two case studies and recommendations are suggested.
\end{abstract}

Keywords: Chintrepreneurship; government intervention; dual-track policy system; regional disparity; autocracy; cronyism; collectivism vs. individualism; mechanism of entrepreneurship; innovation; private ownership right; BRIDGE model

\section{Introduction}

Conventional framework of economics (ex.: laissez-faire with invisible hand) stipulates that, entrepreneurs are those individuals, willing to take risks to invest in new technologies and innovations, in the hope of creating market demand and generating business values. Often the case is that, an industrial revolution may be triggered, giving birth to new industries to massively promote the newly innovated products and services. For example, the emergence of information technology gives birth to internet, e-business and m-commerce industries, changing the entire way of life ever. Following this line of logic, entrepreneurship has been branched out of management science and diverged into a discipline with a bunch of questions remained to be explored, including but not limited to: what theoretical progresses have been advanced from Schumpeterian framework of long waves? What is the theoretical nature of entrepreneurship in today's globalized economy? How can a new wave of entrepreneurship be cultivated to catalyze the economic competence of developing countries in today's global economic downturn? Why more and more disastrous news has been reported by Wall Street (the financial empire) in today's economy than in the past? Why one after another former entrepreneurial star has metamorphosed into crooks in today's economy? Why is it more 
difficult in today's economy to build a loyal consumer clientele and supply chain, than in the past?

Answers to these questions may help to ameliorate limitations, weaknesses and misconceptions of the extant literature, and to systematically theorize the deviations of the formational and functional mechanism of entrepreneurship between developed- and developing- countries. Therefore, this paper aims theoretically, to enrich and deepen the understandings of entrepreneurship in today's' rapidly intensified and globalized business environment, and practically, to recover public confidence and trust to entrepreneurship as a solution for the presently depressed global economy.

\subsection{An Unsettled Concept - Is Entrepreneurship the Cause or the Consequence to Economic Growth?}

The term "entrepreneur" is referred to anyone who is able to identify frequently unrecognized opportunities, to create a new start-up business, to offer innovative or technological ways to transform those opportunities into new products/services and market values. To this end, the defining characteristic of entrepreneurship is genetically traceable to the academic pedigree of Schumpeterianism that, innovations and technologies constitutes the perennial gale of creative and destructive forces, to destroy or annihilate the old ones, while to create and replace them by new ones, and to propel the incessant and intrinsic process of industrial and economic mutations, even during the periods of economic downturns (Schumpeter, 2008[1942]). The essence of Schumpeterian creative destruction theory emphasizes the dynamic power of innovation, which is also defined as a genetic force of maximizing the value of outputs (productivities) from the inputs (resources), and hence, guiding industrial and economic evolution (Drucker, 1985). Aligned with this line of thought, entrepreneurship is described as a channel, for working class to become Burgeoning Bourgeoisie (The Economist, 2009b), and entrepreneurs is worshiped as business heroes (The Economist, 2009a), especially in propelling an economic renaissance during financial crisis and economic downturns(Note 1).

Up to date, GEM (Global Entrepreneurship Monitor), initiated in 1998 by Babson College, is perhaps one of the mostly cited comprehensive initiatives in collecting annual data, comparing and analyzing the impacts of entrepreneurship on national economic performance across national boarder (OECD, 2002). Using a longitudinal data (1988-1999), GEM estimated a nation's entrepreneurial activity by the share of individuals among the nation's entire labor force, who either involved in starting a new venture, or managed a business in less than 42 months. The results showed a significant linear relationship between a nation's entrepreneurial activity and its economic growth (Kantis, et al., 2002). Similar findings have been reported by using different variables. For instance, based on a sample of 14 manufacturing industries selected from 13 European countries, some scholars examined how the share of small firms may affect the output growth of the belonging industries. The results indicated that, an industry with high share of small firms in one country performed better in the subsequent 3-4 years, than the same industry with lower share of small firms in other countries (Carree \& Thurik, 1998). Additional findings showed that, the intensity of market competition is linearly associated with the increased number of competitors, the increased share of entrepreneurs within the same industry, and consequently, the increased growth of industrial productivity (Nickell, 1996; Nickell, Daphne \& Neil, 1997). Some scholars claimed that, it is impossible for a country to have a high level of entrepreneurship, but simultaneously, a low level of economic growth (Reynolds et al., 2002). Furthermore, the level of a nation's entrepreneurship often determines its industrial transformation, from large shares of large enterprises to large shares of small- and medium-sized enterprises (Thurik \& Wennekers 2001; Friijs et al., 2002). Such a transformation may reflect the combinative result of technological advancement and globally intensified competition, forcing large firms to adopt outsourcing strategies in order to achieve cost-advantages by exploiting the potentials of those ambitious and innovative entrepreneurs or SMEs with flexibilities and propensities to accommodate those technological and managerial talents (Audretsch \& Thurik, 2001; Carree \& Thurik, 2002).

In addition to the above ontological approaches, an institutional perspective has been established and applied to examine the relationship between entrepreneurship and economic development, stipulating that, the process of entrepreneurship is leveraged or adjusted through the process of institutional evolution. Without a well-established institutional system, entrepreneurship cannot even get a kickoff (Boettke \& Coyne, 2003). Although, the mainstream of literature contends that, entrepreneurship is linearly associated with economic growth, however, how such a causal the mechanism can be cultivated, developed and managed seems to be an unanswered question, discounting the generalizability of previous findings. A tacit consent that entrepreneurship leads to economic growth in the absence of institutional system seems to be conceptually misleading. Furthermore, the role of government intervention must be added in order to objectively evaluate the linear flow from institutional setting, through the development of entrepreneurship, and to economic growth (Zhao \& Zhang, 2016; 2017).

Critiques argue that, in the discussion of entrepreneurship, previous literature may have overly stressed individual role, while neglected the power of collective wisdom and synergy. Quoted from Professor Qian that: “...... the 
China-way of entrepreneurship is a government oriented approach, effective in lowering the threshold for the mass-entrance, rather than a few entrepreneurs, so that the market can be disturbed more faster than ......" (Note 2). Traditionally, entrepreneurship is essentially privileged to those ambitious individuals, aspired to destruct the old ways of doing business and replace them by innovative ones. Therefore, entrepreneurs must be knowledge and technology oriented in order to differentiate them from opportunists (Nwaobi, 2012). Nevertheless, individualism vs. collectivism in the formational and functional mechanism of entrepreneurship remains to be explored. Facing these unsettled issues, this paper argues that, the weakness of the extant knowledge on entrepreneurship must be acknowledged and discussed. Overly depending on the experience of developed economies to explain the situation of developing countries seems to be a prejudiced roadmap (Zhao \& Zhang, 2016; 2017). Lacking a robust methodological design for data collection and measurement from those developing countries makes previous research findings weak in terms of validity, reliability and generalizability (Torres, et al., 2012). Note that, the measurement of economic growth goes far beyond the numeric magnitude of increased/decreased outputs (i.e. income per capita, productivity, or monetary quote). Without systematically quantifying the impacts of entrepreneurship on the economic dimensions (i.e. poverty alleviation, employment rate, public health, quality of household life, and social well being), within a specifically defined timeframe, political, social, economical and cultural system, the validity, reliability and generalizability of the theoretical constructs on the causality of entrepreneurship and economic growth may be ruthlessly discounted (Zhao \& Zhang, 2016; 2017).

\subsection{A Dilemmatic Trade-off between the Delayed Delivery of Innovation and Early Bird Strategy}

The Ewing Marion Kauffman Foundation, arguably the world's leading think-tank, defined that, 'replicative innovation' and 'innovative innovation' should be viewed as the two transitional phases of entrepreneurship (Note 3). Replicative innovation pervades mostly in developing economies as their catch-up strategy, due to their lack of technological capability. In contrast, Innovative innovation prevails mostly in developed economies, obliging to pursue a competitive or early bird strategy(Note 4). William Baumol, a leading economist, focused on the dilemmatic relationship between innovation and entrepreneurship, and argued that, the optimal timing, speed and frequency of innovations are vital factors in the process of entrepreneurial decisions, and that, the longer the delivery of R\&Ds, the more improvement or newness, and hence, the more achievable market value. However, a delayed delivery of innovation also gives competitors an opportunity to enhance their products/services. Therefore, a trade-off decision over the market opportunities is always a dilemma encountered by entrepreneurs (Baumol, 1993). To Baumol, entrepreneurship is a deviation from established business patterns and practices, partly determined by the capability of innovation supply, partly determined by the market incentives rewarded from the contribution of innovations, and ultimately, determined by the specific settings of political, social and cultural norms in a specific society (Baumol, 2015).

A recently proposed peculiarity framework argues that, the varied forms of creating newness (new products and services, or new ways of doing things) determines the formational and functional mechanism of entrepreneurship, which is vitally determined by the peculiarly structured political-social, institutional and cultural settings within a specific timeframe (Zhao, 2016; 2017). In China for example, although a spectacular growth of economy, entrepreneurship is loosely associated with proprietary innovations. Instead, it is largely a result of rapidly massed imitative entrepreneurship, abetted and nurtured by its historically inherited autocratic, bureaucratic and cronyism-oriented political-economic system (Zhao, 2016). Given their limited technological and financial capabilities, creative or radical innovations are barely feasible in those developing economies. Instead, imitative innovation is their widely pursued way of entrepreneurship (Schmitz, 1989). According to GEM 2002 report, based on a survey of 37 countries representing about 62 per cent of the world population, 460 million adults around the world were engaged in activities of imitation or replication rather than breakthrough innovations(Note 5). Two-thirds of the surveyed entrepreneurs were opportunity-oriented, while the rest are survival- oriented, trying to start businesses because they had no other job opportunities (EMPRETEC, 2004). By imitation/replication, entrepreneurs of developing countries can absorb, accumulate and even establish their own knowledge through the curve of learning-by-doing at minimum cost (Schmitz, 1989; Zhao, 2014; Zhao \& Zhang, 2016). This may help explain why, although China was not appraised as a competitive country of innovation by a range of GEM dimensions (such as fear of failures, entrepreneurial intentions and efficiency-driven and so forth), nevertheless, it was ranked as one of the most competitive countries with better entrepreneurial performances than the average of those being surveyed (Note 6).

\subsection{Why Does an Economic Downturn Provide Opportunities of Entrepreneurship?}

According to Schumpeter (2008[1942]), a new economic pattern always evolves from its declining predecessor. 
Economic downturns may act as a cold shower, awakening companies to strive to innovate smarter ways of doing business, forcing capitals and labors to be liberated from those dying sectors, or replaced by a new generation of entrepreneurs and innovators. The most commonly observed phenomena during the economic downturns may be described as a combination of the reduced cost of business operations and the increased mobility of talents and skilled labors being released from those also-rans. To this end, an economic downturn is thought of a right timing for entrepreneurs to survive and thrive. Many high-tech companies (Microsoft, Hewlett-Packard, Geophysical Service (now Texas Instruments) and Genentech), as well as most (if not all) of those Chinese companies, were born and nourished during economic recessions. Opinion polls of 2008 Endeavor's survey (carried out in eight emerging markets) suggested that, majority of the surveyed entrepreneurs were confidently expecting a business growth of $31 \%$, and increase rate of workforce of $12 \%$ in the year. Over $50 \%$ of the surveyed entrepreneurs believed that they would be able to hire more and better talents, and 39\% of them became more optimistic to their respective competitive strengths(Note 7).

It must be noted that, the increasingly globalized and intensified IT-dominated business environment has served as a catalyzing platform to expedite the turnover cycle of innovative ways of doing businesses. The law of the 'fittest of survival' is to make those good ones better in an incremental rhythm. For instance, in the mid of last century, the ranking of the Fortune 500 was so stable that, once constituted, it was kept for 20 years until the next round of selection, which is now scheduled to take place in every four years. From economics point of view, economic downturns may provide supportive advantages for the development of IT-oriented entrepreneurship. On the one hand, the relentless nature of IT-competition deprives the privileges of those incumbents. It is argued that, the beginning point of an entrepreneurial process stimulates a path-breaking point, where the transaction cost of business operations within a stereotyped market system exceeds the cost of doing the same business in a newly emerged and diversified market system (Coase, 1937). On the other hand, IT-innovations may trigger a shift of economic pattern from manufacturing-oriented to service-oriented. Such a transformation may lower the entry barrier for new comers, given the fact that, service firms are relatively smaller, flexible in operations, and easy to start off.

\section{Objectives of This Paper}

Methodologically, literature review, interviews with researchers, business executives, policy-makers and government consultants, and in-depth desktop data analysis, are used to compare and discern the similarities and the dissimilarities between Chintrepreneurship and traditionally conceptualized entrepreneurship in terms of their respective mechanism. The overall objective of this paper is to rationalize the mechanism of government intervention oriented entrepreneurship (Chintrepreneurship), and to argue that, it is a more valid and competitive mechanism now than ever, in stimulating and incentivizing the capability of innovation and economic catch-up for developing economies. The primary goal of this paper is to logically theorize that, if without understanding the formational mechanism of Chintrepreneurship and its functional role in transforming global economic pattern, from the previously polarized and monopolized by a few industrialized countries, into the presently depolarized and diversified by the increasingly emerged economies, it would be too difficult to interpret the co-evolution of the dynamic vibrancy of entrepreneurship and the ever-changing nature of business environment. This paper endeavors to argue that, if without acknowledging the respectively differentiated social-economical impacts resulting from collectivism-based Chintrepreneurship and individualism-based entrepreneurship, it would be too difficult to rationalize the theoretical dilemma that, why the democracy and free-market competition oriented entrepreneurship can be incubated in China, a politically autocratic and cronyism oriented society. Another argument of this paper is that, if without taking into account the role of government intervention, the cognitive development on the mechanism of entrepreneurship and its impact on forging a nation's economic capability and competitiveness, would be trapped in a dead-end of traditional framework.

\section{Literature Review on the Theoretical Development of Entrepreneurship}

Theoretically, there have been five approaches addressing the developmental mechanism of entrepreneurship. The first is the Growth theory, focusing on elements that can be used to examine and evaluate the causal relationship between entrepreneurship and economic growth. The second is the Agglomeration theory, emphasizing the aggregated roles of knowledge, technology and innovation in promoting the development of entrepreneurship, meanwhile, promoting knowledge management to deal with an increasingly exacerbated challenges for proprietors to prevent knowledge leakage or spillovers, imitators and/or copycats from eroding and discounting the early birds' advantages. The third is the Globalization theory, emphasizing the roles of increasingly globalized and diversified 
entrepreneurial patterns due to the intensified competition of value chains and supply chains, from traditionally labor and material oriented production competition, to presently information-technology oriented innovation competition across national borders (Zhang \& Stough, 2013). The fourth is the theory of peculiarity, specifying the nature of time-and-space to the mechanism of entrepreneurship, which is intrinsically limited to a nation's political-social, institutional and cultural settings across time (Zhao, 2016). The last is the government intervention theory, stipulating that in those politically-controlled economies like China, government functions as the planter to cultivate entrepreneurship (Zhao, 2017). Epistemologically, these five theoretical stances seem traceable to the origin of historically inherited two camps, namely: Schumpeterianism and Keynesianism, equivalently representing the two antithetical camps between the democracy and the free market oriented entrepreneurship (Washington Consensus) and the autocracy and the government intervention oriented entrepreneurship (Beijing Consensus) - which one of them is more constructive is a theoretical challenge for both present and future researchers (Zhao, 2016; 2017).

Schumpeterianism stipulates that, autocracy and bureaucratization are the killers, obstructing the development of entrepreneurship, which is accordingly defined as the prop of a strong economy, driven by entrepreneurs' creative and destructive innovations (Schumpeter, 1942). In contrast, Keynesianism favors the role of big government in creating an orderly prosperity (Keynes, 1920). What makes Schumpeterianism essentially differentiated from Keynesianism is their respective attitude to the developmental mechanism of entrepreneurship. Sociologically, it is argued that, adapting, habituating and complying with the power of government of either type, democratic or autocratic, is an inherited gene throughout human history - therefore, risking the turmoil to chase creative destruction and market competition is equivalent to the waste of resources (Keynes, 1920). As he prophesied that, when it comes to a financial crisis and a subsequent recession/depression, the entire business world would scream and struggle for government support - this is why government intervention is thought to be an effective treatment or cure during an economic downturn (Keynes, 1920).

\subsection{From Schumpeterian Agent Theory of Creative and Destructive Force to the Tripartite Model}

Some scholars endeavored to study entrepreneurs' capabilities of perceiving and capturing emerging opportunities, or, generating, disseminating and implementing new business concepts/ideas to organize and re-organize institutional resources, to cope with uncertainties, and to create profit (Carree \& Thurik, 2002; Dejardin, 2000; OECD, 1998; Wennekers \& Thurik, 1999). Other scholars emphasized that, the functional role of entrepreneurs in business operations may be summarized as coordinating, innovating, risk taking, decision making, capital supplying and resource allocating (Barreto, 1989; Friijs et al., 2002; Jääskeläinen 2000). It is argued that, it is more meaningful to study entrepreneurs' consistent behavioral characteristics, rather than one-time activities (Pirich, 2001). These scholastic contributions may be traced and rooted into Schumpeterian framework of agent theory, stipulating that, entrepreneurs function as the driving force in compelling the development of tripartite relationship among innovation, entrepreneurship, and economic growth (Schumpeter, 1934). When historical dimension is added, economic development is defined as a long wave of unevenly distributed innovations initiated stochastically via agents' efforts (Schumpeter, 1942).

Agent theory stipulates that everyone can be an agent, as far as he/she is able to create a combinative force of new innovations, new products/services, and/or new management models. Such a combinative force should be not only creative but also destructive to make the existing ones obsolete or replaced (Schumpeter, 1934; 1942). To this end, it is the creative and destructive force of agents that constitute Schumpeterian tripartite model, namely, the path-dependent process of cyclical waves from innovations of entrepreneurs, through industrial upgrade, to the dynamic growth of economy. Enlightened by Schumpeterian tripartite model, this paper proposes a three-staged model to outline the developmental mechanism of entrepreneurship (See Figure 1):

Figure 1 indicates that, any entrepreneurial process is always traceable to an individual ambition and capability of innovation. Therefore, entrepreneurs' knowledge scope, network resource availability or proximity, and psychologically endowed risk-taking propensity are necessary conditions to ensure the three-staged process of entrepreneurship, from agents (entrepreneurs) searching/creating novel ideas/concepts (Stage 1), through transforming ideas/concepts into innovative business operations (Stage 2), to commercializing and industrializing the innovative products/services, by establishing newness and critical mass to disrupt the existing market (Stage 3). The loop of three-stages is the core prop of sustainable development of entrepreneurship. 


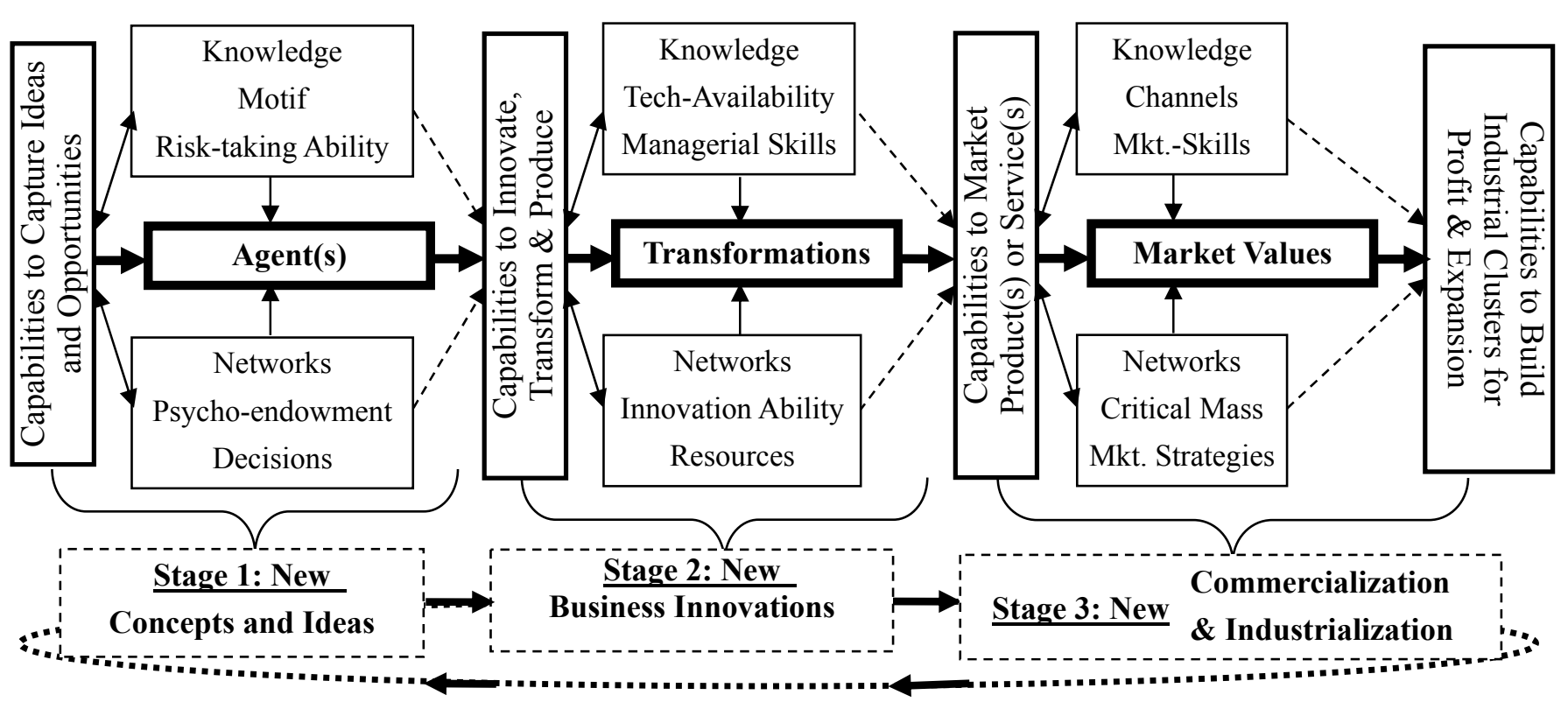

Figure 1. A Three-Staged Model for the Sustainable Mechanism of Entrepreneurship

\subsection{From Keynesian Government Intervention to the Tripartite Model}

The marrow of Keynesianism contends that, the function of government intervention is indispensable from the formational mechanism of entrepreneurship. In 2002, the U.S. Congress, in response to Enron scandal, launched the Sarbanes-Oxley legislation with a spearhead pointing at corporate governance, making entrepreneurship more difficult than ever. Such a government reaction is in sharp contrast when compared with China government's let-go attitude in the face of financial scandals and various unethical and criminal business activities (Note 8 ). Over $40 \%$ of China's online sales provide counterfeit or fake products of those globally renowned brands, deceiving and depriving both IPR and consumers' right. Among millions of online vendors, Alibaba is the most notorious host of e-commerce platform in China(Note 9). These examples explain that, the confinement of government intervention to the developmental mechanism of entrepreneurship does exist, and that, the respective political power distribution and redistribution determine the respective ways of pursuing business opportunities, organizational patterns, and business creed (Marris \& Somerset, 1971; Zhao, 2014; 2016; 2017). For example, the historically inherited autocratic political system determines the fundamentally differentiated economic and entrepreneurial mechanisms between China and Western societies. The success of the past 40-years' economic growth may serve to support Keynesianism, and legitimize the effectiveness of government intervention in boosting the development of entrepreneurship (Zhao \& Zhang, 2016; 2017). One example to elaborate the effectiveness of government intervention is the transition of ownership. By launching a series of policies, part of SOEs have been privatized and transformed from previously government sole ownership to a board of collective owners but with appointed or designated party-members as top leaders (red-hat entrepreneurs). The red-hat enterprises can opt to register as POEs, and behave like chameleons, sheltered under SOEs' umbrella, but guaranteed not to be crowded out from private sectors. This is the peculiarity of China-way of industrial reformation, which allows SOEs to receive state budget as their primary source of venture capitals. Such an exclusive privilege is absolutely not available and accessible to those non-red-hat entrepreneurs (Zhao, 2016; 2017).

A typical example to explain the role of government intervention is the aggressively promulgated and implemented strategic policies, guiding China economic reformation, through industrial consolidation, privatization, diversification and globalization, resulting in some emerging but fast growing industries such as telecommunication and finance, significantly contributed to the growth of China GDP and economic transition. To support innovation, government has sponsored the 'Innofund' (a public venture investment program), dedicated to finance the high-tech innovation and entrepreneurship. Although much to be improved, however, Innofund has stimulated and incentivized the development of entrepreneurship, and meanwhile, prevented the chances of speculative behaviors, such as rent seeking, as well as coercive monopoly of incumbents (Zhang \& Stough, 2013). In a sense, the government of China is the bundling nexus, connecting the nation's innovation, entrepreneurship with its industrial transformation and economic growth (Zhao \& Zhang, 2016; 2017). 


\subsection{Theoretical Need to Upgrade the Framework of Entrepreneurship for Emerging Economies}

Seemingly, both Schumpeterianism and Keynesianism have explained the formational and functional mechanism of entrepreneurship from their respective perspective, however, each of them, when examined independently, exposes its respective limitations in rationalizing the tripartite relationship from innovation/entrepreneurship, through industrialization, to economic growth. It is suggested that, when an economic system enters the phase of industrialization and capitalization, then, its capabilities of innovations and entrepreneurship may be accumulated and aggregated to the level that will inevitably trigger and propel a qualitative change of a nation's economy (Peretto, 1999). Given that the two theoretical frameworks are crystallized from developed economies in Western societies, this paper argues that, they must be adjusted or upgraded, in order for the tripartite framework to be able to appropriately and objectively explain the rapidly emerged economic phenomena (Schmitz, 1989).

Interestingly, entrepreneurship has been discussed more as a subject of psychology and sociology, focusing on cultural and social conditions associated with entrepreneurs' personal traits (ex.: propensity of risk-taking), than as a subject of management (Zhao, 2016). Correspondingly, a systematic framework capable of explaining the formational and functional mechanisms of entrepreneurship in promoting economic development is still weak, if not absent (Baumol, 1968). Pragmatically, how to stimulate a nationwide impetus of R\&Ds and entrepreneurship across regional and cultural disparities, how to minimize the marginal cost of transforming resources into market values, and ultimately, how to convert government intervention (policy and regulation) as a resource, and integrate it into the process of entrepreneurship - they are the emerging but challenging questions that will help contemporary scholars to shake off the shackles of traditional framework, so that the dynamically globalized and diversified economic pattern become fathomable and/or predicable (Zhao \& Zhang, 2016; 2017). Furthermore, from the perspectives of resource-based view and dynamic capability approach, the consolidated network resource (ex.: political, social, institutional and cultural settings) may be more vitally decisive than the traditionally emphasized personal traits for entrepreneurship. This is especially true in those emerging economies like China, wherein, autocratic bureaucracy and cronyism oriented capitalism dominate its economic system (Zhao \& Zhang, 2017). Accordingly, how to integrate these generic but non-market type of resources, and convert them into value-adding and competitive advantages for the development of entrepreneurship, becomes a critical research question (Yiu \& Lau, 2008). After all, innovation and entrepreneurship are crystallized from human wisdom, catalyzing the transformational speed of resource inputs to value outputs, by breaking the idled or sluggish processes, while replacing or upgrading them by innovative ones over and over again across time and space.

Imprudently in a sense, it was claimed that, when the macroeconomics garnered the most attention, entrepreneurship seems to become a forgotten pond of backwater (Galbraith, 1967). Such a misconception was overthrown when Joseph Schumpeter launched his theory of creative and destructive force of innovation, stipulating that, the key to business competitiveness is no longer the scale of mass production and the price of product, instead, it is the combination of new ideas and resources, enabling innovators and entrepreneurs to generate new technologies as creative forces to destruct old ways of doing business, replace them by new ones, and consequently, revitalize a new round of economic growth (Schumpeter, 1934; 1942). To this end, the glory of Schumpeterian framework deserves to be once again revitalized or revamped, to open up a whole new avenue to explore the causal mechanism of innovation, entrepreneurship and economic growth in both developed and developing economies (Abzug et al., 2000; Birch, 1979; Haltiwanger et al., 2011; McCraw, 2010; Medoff \& Birch, 1994; Phelps, 2013; Wong et al., 2005). It must be noted that, in the face of the explosively emerged information technology along with the rapidly globalized business environment during the past three decades, the attitude of some developing countries' government toward the concepts of POR and entrepreneurship are still hesitating or panic, if not against, mainly because of potential risks that might jeopardize their entrenched political-social interests (Cooper, 2010; Ogilvie, 2011; Rodrik \& Rosenzweig, 2010).

\section{Decisive Conditions for the Developmental Mechanism of Entrepreneurship}

It is argued that, entrepreneurship does not happen in a vacuum. Instead, it happens within a specifically defined time-and-space, namely, a specifically structured political-social and cultural system. Therefore, discussions of entrepreneurship must be confined correspondingly.

\subsection{A Resource-based View on the Mechanism of Entrepreneurship}

Howard Stevenson defined entrepreneurship as a process of pursuing opportunities beyond the control of available resources (Stevenson, 1983). This definition is described as the 'best answer' by the INC Magazine(Note 10), 
stipulating that, the magnitude of resource availability determines whether an entrepreneurial process can proceed (Stevenson, 2000; Stevenson \& Gumpert, 1985). To Stevenson, political environment and administrative settings are critical resources that can either foster or destroy the developmental mechanism of entrepreneurship (Stevenson, 1983). To cultivate and sustain the momentum of entrepreneurship, both environmental conditions (exogenous) and entrepreneurs' capabilities (endogenous) must be established (Barreto, 1989).

As a complement, it is argued that, the institutional capabilities of regulating, normalizing and standardizing R\&Ds and Innovations, the managerial capabilities of organizing and controlling necessary resources, and the technological capabilities of manufacturing, commercializing or converting resources into market values (salable products/services) - they are the three resource-based infrastructural conditions, either facilitating or constraining the developmental mechanism of entrepreneurship (Van de Ven, 1993). In line of this thought, entrepreneurship is a socially, institutionally and collectively engaged process of doing new business, or doing business in new ways, rather than focusing exclusively on the individualism, namely, the individual characteristics, attributes and inclination of risk-taking behaviors (Zhao \& Zhang, 2016; 2017). To a certain extent, a nation's capability of entrepreneurship determines the pace of its industrial revolution and evolution. While, technological capability represents its intrinsic power to knock down the existing market and industrial boundaries (See Table 1):

Table 1. Endogenous and Exogenous Conditions for the Development of Entrepreneurship

From the perspective of personal traits, the origin of any innovation or entrepreneurial activity can be traced to a single person. According to McClelland's findings, individuals are the agents of entrepreneurship, they are motivated with clear proclivity to make things happen, generally tinged with the following ten personal entrepreneurial competencies (PECs), namely, opportunity-driven, risk-taking, efficiency and quality

Endogenous demanding, persistent, commitment to contract, information vigilant, goal-oriented, systematic planning and monitoring, persuasive and networking, and independence and self-confidence (McClelland 1961; 1965). Therefore, the key is to identify and select individuals with potentials, provide trainings to upgrade their skills/abilities, and advance their entrepreneurial performance and competence (EMPRETEC, 2004; EDECU, 2002).

The success of entrepreneurship is largely determined by a specifically structured political, institutional, social, economical and cultural system (Baumol, 1990; Van de Ven, 1993). Government interventions (i.e. policies and regulations) possess the critical impact on the development of entrepreneurship. This is especially true in those developing countries like China, wherein, autocracy, rather than democracy, dominates the economic environment (Zhao, 2016; 2017). In contrast, a democratic and market oriented environment may enable entrepreneurs to interpret market signals of demand and price, and respond accordingly (OECD, 1998). Therefore, the role of government intervention may be summarized as:

- Government can guide social, institutional and legal systems to establish a bankruptcy system, make them not hostile to bankrupted entrepreneurs, and allow those unsuccessful enterprises to restructure or close down, so that, the resources liberated from them can be allocated to other promising business

Exogenous ventures. For instance, in some European countries, bankruptcy is perceived as a personal failure bearing a social stigma. Bankrupted entrepreneurs are forced to settle all their debts, severely discouraging or preventing them from using their experiences to start a new firm. In contrast, US bankruptcy system is commonly deemed as a reasonable outcome of a 'good try', or a stepping stone for starting a new business, allowing resource redistribution from the failed to those promising and competitive ones (OECD, 1998). Such a government sheltered bankruptcy system can not only encourage the tempted entrepreneurship, but also foster the viable causes of employee ownership and organizational entrepreneurship (OECD, 2002).

- Government is the key to unlock the latent resources and potentials, and support a nation's entrepreneurship social prosperity. By providing and safeguarding an equal right of opportunity and resource, disadvantaged groups (ex.: women entrepreneurs) are also encouraged and stimulated to participate (Reynolds, et al., 2000).

Table 1 explains that, given the unavoidable, irreplaceable and decisive role of government in forming the endogenous and exogenous conditions, namely, the threshold of entry and exit of entrepreneurship, improving the quality of government intervention to stimulate and incentivize the development of entrepreneurship seems to be the 
top challenge especially for those developing and transitioning economies (Zhao \& Zhang, 2016; 2017). Despite the deviations of social, economic and cultural impacts from region to region, country to country, the absolute power of government to disrupt and adjust the formation and function of both endogenous and exogenous conditions remains the same regardless of developed- and developing economies. Note that, overly emphasizing the endogenous conditions (individual traits) may trigger a flurry of debates, misleading the cognitive development. Exogenous conditions such as political systems and cultural disparities may exert severe impacts on the development of entrepreneurial traits (Müller \& Abisya, 2001). In addition to the indelible contribution of government intervention to the formation and function of Chintrapreneurship in China (Zhao, 2016; 2017), EMRETEC, a Spanish acronym for entrepreneurs and technology, a global program firstly launched and implemented in Argentina by United Nations Conference on Trade and Development (UNCTAD) in 1988, and then introduced to other developing countries, is another example to showcase the impact of exogenous condition on the development of entrepreneurship.

It is worth to note that, EMPRETEC is a one-stop-shop ETW (Entrepreneurship Training Workshop) program, to motivate and inspire those potentially talented individuals to enhance their PECs (personal entrepreneurial competencies). Candidates, after a careful selection process, are required to undergo a two-week close-door workshop, accepting in-house advices and trainings, including but not limited to change management, marketing, quality control, productivity improvement, accounting practices, financial management and negotiating skills - all is aimed to enhance candidates' entrepreneurial skills, abilities and competencies. Tested results show that, more than $85 \%$ of those trainees after completing the program and returning to their respective home countries have demonstrated a noticeable change in terms of their business attitude, entrepreneurial commitment and performance (EMPRETEC, 2004). An impact analysis of a 10-year period of EMPRETEC program in Brazil indicates that, a remarkable improvement of environmental condition for entrepreneurship has been detected and linearly associated with the implementation of EMPRETEC program. The total number of the nation's entrepreneurs has been doubled with improved business performances, labor productivity has been enhanced, and employment rate has been increased (EDECU, 2002), indicating that, exogenous support (both government and non-government) is critical and decisive. Until 2004, the EMPRETEC program via its localized business centers, has trained and assisted more than 80,000 entrepreneurs from 27 developing countries, generated enviable results to the promotion of regional momentum and impetus of entrepreneurship(Note 11).

\subsection{Similarity and Dissimilarity of Entrepreneurship between Developed and Developing Economies}

Given the autocratic political system, limited technological and financial capabilities, entrepreneurship is conventionally prohibited or dismissive in most of those developing countries. However, globalization has reshaped the traditional economic structure, incubated a rapidly and massively emerged generation of entrepreneurs, one after another, erected from those developing economies (i.e.: Asian Dragons, African Lions, and golden BRICS). These rising stars have demonstrated their tenacity and dynamism, and proved themselves as a disruptive force to the polarized and stagnated global economic environment (Zhao, 2016; 2017). However, to what extent, the similarity and dissimilarity of the formational and functional mechanism of entrepreneurship can be differentiated between developed and developing economies is an imperative challenge to objectively reflect the increasingly globalized and diversified phenomena of entrepreneurship. This paper proposes that, analyzing and rationalizing the role and impact of government intervention may best serve to fulfill this theoretical need. What is the rationale of policy-necessity in the development of entrepreneurship? Assuming the policy-necessity possesses the theoretical validation, then, how can a policy be designed and institutionalized to stimulate a sustainable mechanism of entrepreneurship? Answers to these questions may help explain some already observed, but not yet rationalized deviations of the developmental mechanism of entrepreneurship between developed and developing economies (See Table 2).

Table 2 emphasizes either implicitly or explicitly that, the dynamic nature of time-and-space oriented entrepreneurship, which varies from time to time, location to location, and society to society, is the missing point in the existing literature. Government intervention, aside from other factors, is the key to distinguish the mechanism of entrepreneurship between developing- and developed- economies. It is contended that, government intervention, if properly designed, executed and institutionalized, can act as a value-adding factor to incentivize the momentum of innovation and entrepreneurship, and meanwhile, prevent those malfunctioned entrepreneurial behaviors such as rent-seeking, copycatting or imitations (Zhao, 2016; 2017). 
Table 2. Similarity and Dissimilarity of Entrepreneurship between Developed and Developing Economies

Taking risks, capturing opportunities, organizing resources, and converting them into competitive advantages and profit-making processes within a specifically defined timeframe and a specifically

Similarities defined political, economical, social and cultural environment, together, they constitute the similarities in the developmental mechanism of entrepreneurship, across time and space (Zhao, 2014; 2016; 2017).

Government intervention (policy and regulation), rather than market competition, is the driving force to propel the development of entrepreneurship in developing countries, especially in a politically autocratic country like China (Zhao \& Zhang, 2017). Given the autocratic nature of government in developing countries:

Dissimilarities

- complying with and taking advantage of government policies seem to be critical and decisive to the mechanism of entrepreneurship (i.e. capture opportunities, lobby investors, and incentivize market consumptions), however,

- when policy-makers were not well-informed or not equipped with required knowledge, it is likely to have policies improperly designed and executed, leading to misdirection of entrepreneurship.

Although empirical validation is needed, the correlation between government interventions (policies and institutions) and entrepreneurship is widely witnessed. According to the ranking results of World Bank's Doing Business index measured by the ease of doing business, China and Brazil are the two developing countries having achieved a rapid progress respectively, in promoting the development of entrepreneurship through government interventions (Note 12). Although China government has greatly endeavored to facilitate the ease of doing business by promoting entrepreneurial policies in many respects, such as lifting the restrictions in some industries, lowering the entry threshold of new business, investing in infrastructures, transforming and privatizing SOEs, and financing indigenous innovations. Nevertheless, the contribution of POEs to the growth of national GDP is too tiny to compare with those SOEs - primarily because that, the benefits of government intervention can only be captured and embraced by those pseudo- or quasi- entrepreneurs, or pure opportunists, who are associated directly or indirectly with the cronyism-oriented bureaucratic government system (Zhao \& Zhang, 2016; 2017). In contrast, the contribution of entrepreneurship reaches $40 \%$ of United States economy(Note 13). Given these research findings, it is argued that, the linear relationship from entrepreneurship, through industrialization to economic growth in those developing countries like China, cannot be measured and evaluated, if without adding government intervention as an adjustor. Otherwise, the generalizability, reliability as well as of the validity of measurements would be biased (Zhao, 2017).

\section{Upgrading the Definitions of Entrepreneurs, Entrepreneurship/Intrapreneurship}

Previous literature abounds with definitions of entrepreneurs, entrepreneurship/intrapreneurship, however, these concepts seem fragmented, lacking a universally benchmarked criteria system, so that researchers and practitioners can communicate on a systematically defined theoretical platform.

\subsection{Three Critical Criteria to Evaluate the Process of Entrepreneurship}

Despite that OECD (1998) has launched a measuring system to monitor and evaluate the relative shares of entrepreneurial contribution to a nation's economic growth. However, its methodology of data collection seems lack of validity and reliability. For instance, the number of entrepreneurs was represented by the net entry of new firms, but their business performances remained unmeasured. To fill this need, two groups of scholars delved into the construction of performance criteria to evaluate the contribution of entrepreneurship to economic development. The first group emphasized the role of individual qualifications (traits and capabilities) in promoting the change of micro-environment (Carree \& Thurik, 2002). The second group endeavored to examine the impact of macro-environment on the development of entrepreneurship(Note 14). The two groups are mutually complementary in constructing a measuring system composed of three critical criteria, namely, newness, social capitals (network resources), and critical mass (See Table 3): 
Table 3. Three Critical Criteria to Examine and Evaluate the Process of Entrepreneurship

Criteria 1: Newness of Technology and Innovation

According to Zhao (2014), 'New-to-the-world' innovation barely exists, since knowledge can only evolve in a consecutive order. Break-through technology is a rhetoric word. Instead, 'New-to-the-existing ones' is a realistic term to define the concept of innovation. The degree of proximity and connectivity between the new technology and the existing ones determines the degree of newness. A radical innovation (breakthrough innovation) may be distanced from the existing technologies. An incremental innovation is likely derived from those closely related existing technologies. Either one can act as a sufficient and necessary cause of entrepreneurship (Zhao, 2014).

Criteria 2: Availability or Accessibility of Social Capitals or Network Resources

The availability and accessibility of social capitals or network resources determine entrepreneurs' capability of obtaining the financial, technological and managerial supports (OECD 2002), and hence, the feasibility of transforming ideas and resources into business process and market values. Taking advantage of government policies and regulations is an efficient and effective way to create ideas and opportunities to start a new business or a new project (Zhao, 2016; 2017).

\section{Criteria 3: Critical Mass, Industrialization, Commercialization}

Establishing a critical mass for an innovated product/service is not only the pre-condition for the development of industrial clusters with competitive advantages, but also the pre-condition for the transformation from an idea to a profit-making process. Without establishing a critical mass, industrialization and commercialization would be practically impossible.

Table 3 underlines the three critical conditions for the development of entrepreneurship. Entrepreneurs must be able to seize opportunities, to create newness, to establish a critical mass, and to transform resources into economic values. Social network resources serve as the main channel of entrepreneurship. Large organizations' R\&Ds and innovations are likely to become the sources of SMEs' entrepreneurial opportunities, through spin-offs, technological and knowledge spillovers, outsourcings, as well as supply chain operations (Reynolds et al., 2002).

\subsection{An Updated Definition of Entrepreneurs}

A few questions remained to be clarified. Who are entrepreneurs? What qualifies an individual person to be an Entrepreneur? According to Schumpeter (1975), entrepreneurs, the bedrocks of modern economic breakthroughs, are those capitalistically motivated individuals, capable of innovating and converting knowledge and technology into market competition and profit creation. From value-yielding perspective, it is argued that, entrepreneurs are those innovators, capable of purposefully deploying, redeploying and transforming resources inputs (ex: labor, material, finance and technology), from a low-yield level, to a high-yield level, through an industrial and trading process (Hisrich \& Peters, 2002).

Anecdotally, from the individual traits perspective, entrepreneurs are deemed as solution-providers, doers of making impossible possible, or, risk-takers and profit-creators out of the uncertainties. From the organizational perspective, entrepreneurs are depicted as change agents, capable of creating new business opportunities, organizing and allocating resources, fostering innovations and enhancing business competitiveness. From academia perspective, entrepreneurs are respected as brokers of the most cutting edge knowledge. Notwithstanding these theoretical efforts, the most embarrassing challenge encountered by researchers and practitioners is to define the minimum characteristics and traits that can be used to measure and qualify the type of people as entrepreneurs (See Table 4):

Table 4 demonstrates a short list of congruently acknowledged characteristics and traits distilled from existing literature. An entrepreneur must be able to bridge the gap between knowledge producers and industrial users, and to convert and commercialize scientific and technological advancement into industrial and value-creating process. Using a cross sectional data sampled from two European countries (Sweden and Ireland) respectively, covering gender, age, previous entrepreneurial background and experience, professional specialty and personal attitude to entrepreneurship, the results empirically showed a significant relationship between academic institutions and business entities, but not significant between academic entrepreneurship and creation of new firms or organizational spinoffs (Klofsten \& Jones-Evans, 2000). This result is in a sharp contrast with the case of China, where in, academic 
entrepreneurship has resulted in tens of thousands of POEs divested from SOEs, universities, research institutes and government agencies (Zhao, 2017).

Table 4. Commonly Defined Characteristics and Traits of Entrepreneurs

\begin{tabular}{ll}
\hline \multicolumn{1}{c}{ Perspectives } & \multicolumn{1}{c}{ Characteristics and Traits of Entrepreneurs } \\
\hline $\begin{array}{l}\text { Individuals' } \\
\text { Dispositions }\end{array}$ & $\begin{array}{l}\text { Risk takers and rule-breakers } \\
\text { Pursuers or creators of novel ideas and opportunities that others may fail to recognize or may } \\
\text { even view as problems or threats }\end{array}$ \\
\hline $\begin{array}{l}\text { Individuals' } \\
\text { Technological } \\
\text { Capabilities }\end{array}$ & $\begin{array}{l}\text { Innovators, able to innovate and transform knowledge and technology into business process of } \\
\text { profit making }\end{array}$ \\
\hline $\begin{array}{l}\text { Individuals' } \\
\text { Managerial }\end{array}$ & $\begin{array}{l}\text { Able to create/convert ideas and resources into business operations } \\
\text { Capabilities }\end{array}$ \\
$\begin{array}{l}\text { Able to disrupt and break into an existing market } \\
\text { Able to create new jobs, new markets, or new market segments }\end{array}$ \\
\hline
\end{tabular}

Note: the source of this table is borrowed and modified from Zhao $(2014 ; 2016 ; 2017)$

\subsection{An Updated Definition of Entrepreneurship/Intrapreneurship}

Schumpeterian concept of entrepreneurship still dominates the mainstream of existing literature. Both entrepreneurship and intrapreneurship are referred as the perennial gale of creative force, driving technological advancement, global competition, and economic growth (Schumpeter, 1934; 1942). Intrapreneurship represents an organization's capability and propensity of R\&Ds and innovations (OECD, 1998; Porter, 1990) - an internal force dedicated to overcome the genetically inherited organizational inertias. Comparatively, entrepreneurship is defined as a process of taking risks, capturing opportunities of innovations (Egai, 2008), and transforming the novel ideas and resources into business ventures and market values, and ultimately, enhancing or stimulating the potentials of economic growth (UNIDO, 1999). To complement these theoretical endeavors, entrepreneurship is defined as a process of constantly upgrading the already established business routines, cultivating and enforcing organizational ingenuity of doing new business or doing business in new ways. It is an orderly processed activity flow from searching or creating new business ideas/opportunities, to organizing/allocating resources and transforming them into business operations and market values (Zhao, 2013; 2014; 2016; 2017). Notwithstanding the existing theoretical mosaic, it must be emphasized that, an entrepreneurial process is comprised of interacting, interdependent and multi-facet business activities, rather than any stochastic or casual actions. The dynamically evolving nature of entrepreneurship is still epistemologically underdeveloped. The crux of entrepreneurial mechanism ought to be systematically theorized, in order to fit into and keep pace with the rhythm of increasingly globalized and diversified environment.

\subsection{Defining the Relationship between Innovation and Entrepreneurship}

It is congruently agreed that, the 'Newness' is the defining characteristic of entrepreneurship, aiming to create new business or new ways of doing business, to improve business processes and enhance the productivity and efficiency, both quantitatively and qualitatively through innovation. Therefore, entrepreneurship by essence is a process of innovation, radical or incremental, creative or imitative - representing the revolutionary forces of changing or adding something new to the existing ones. To this end, newness is the least requirement, intolerable for any compromises, in defining and measuring a process of entrepreneurship. Therefore, innovation is a mandatory characteristic in defining the concept of entrepreneurship.

\subsection{Defining a Measurement System to Examine and Evaluate the Performance of Entrepreneurs}

From technological advancement perspective, innovation cannot occur from occasional odds. Instead, it can be only initiated or derived from the process of transforming innovative ideas and technologies into the development of new venture business or the improvement of the existing ones (Hisrich \& Peters, 2002). Innovation is the fundamental measurement of entrepreneurship. Without inculcating the concept of innovation, entrepreneurship is solely an empty word. Furthermore, it must be noted that, if, choosing the best idea to pursue innovation is difficult, then, 
implementing that same idea to start off a new venture business is more difficult. Although, focusing on consumers' needs is a necessary starting point, however, avoiding a cut throat competition may be the rule of thumb for any entrepreneurs to kick off. Given the decisive role of innovation, establishing a measurement system to examine and evaluate personal qualifications (traits and characteristics), and capabilities of searching and capturing the feasible innovation ideas/concepts, organizing and allocating resources, and transforming them into market values, are the key factors to determine whether an individual can be qualified as an entrepreneur (See Table 5):

Table 5. Dimensions to Measure the Capability and Performance of Entrepreneurship

\begin{tabular}{|c|c|}
\hline Levels & Measurements of an Entrepreneur's Qualifications: Characteristics and Traits \\
\hline $\begin{array}{l}\text { Personal } \\
\text { Level }\end{array}$ & $\begin{array}{l}\text { - Information-vigilance, risk-taking and just-do-it in the face of uncertainty and resource } \\
\text { scarcity; } \\
\text { - } \quad \text { Passionate, initiative, aggressive and burn with desire, easygoing and flexible to change; } \\
\text { - } \quad \text { Energetic, diligent, confident, determined and persistent; } \\
\text { Visionary, independent, and self-disciplined. }\end{array}$ \\
\hline $\begin{array}{l}\text { Professional } \\
\text { Level }\end{array}$ & $\begin{array}{l}\text { - Leadership and persuasiveness: able to build and lead a team, and convince followers; } \\
\text { - Innovation-oriented: able to act as change agents and initiate innovations; } \\
\text { - } \quad \text { Network-oriented: able to communicate, coach and organize, vertically and horizontally; } \\
\text { - Competition-oriented: able to perceive and catch subtle signals of business ideas and } \\
\text { - } \quad \text { Strategy-oriented: able to preemptively exit, at a minimum cost, at the right timing. }\end{array}$ \\
\hline $\begin{array}{l}\text { National } \\
\text { Level }\end{array}$ & $\begin{array}{l}\text { The annual longitudinal demographic data (1996-2013) published online by Kauffman Index of } \\
\text { Entrepreneurial Activity(Note 15), shows that, in addition to race, gender and education } \\
\text { background: } \\
\text { - The proportion of adult population engaged in the creation of new businesses, and the } \\
\text { proportion of the new firms that have survived from their respective start-up phase, are two } \\
\text { critical dimensions to measure a nation's performance and competitiveness of entrepreneurship } \\
\text { against the odds stemmed from political, social, cultural, bureaucratic and financial constraints. } \\
\text { As observed that, when entrepreneurs of developing countries migrate to a developed country, } \\
\text { wherein, the strong economic and industrial infrastructures and the positive social and cultural } \\
\text { attitudes give them a head-start. Those successful Indian and Chinese innovators in Silicon } \\
\text { Valley can be used as good examples to explain that, exogenous factors may have more weight } \\
\text { in the development of entrepreneurship than those endogenous ones do. }\end{array}$ \\
\hline Capabilities & Measurements of an Entrepreneur's Capabilities \& Perf \\
\hline $\begin{array}{l}\text { R\&Ds \& } \\
\text { Innovations }\end{array}$ & $\begin{array}{l}\text { - } \quad \text { Ability to initiate R\&Ds and innovations; } \\
\text { - } \quad \text { Ability to transform innovations into salable products or services }\end{array}$ \\
\hline $\begin{array}{l}\text { Responsiveness } \\
\text { to Market } \\
\text { Feedbacks }\end{array}$ & $\begin{array}{l}\text { - } \quad \text { Ability to respond to market feedbacks in a timely manner; } \\
\text { - Ability to analyze and identify deficiency or inefficiency from existing operations, and treat } \\
\text { them as innovation opportunities for improvement, both technologically and managerially. }\end{array}$ \\
\hline $\begin{array}{l}\text { Leverage } \\
\text { Government } \\
\text { Interventions }\end{array}$ & $\begin{array}{l}\text { - Ability to understand and take advantage of government interventions (policies \& regulations); } \\
\text { - Ability to make use of government interventions and convert them as business resources to } \\
\text { stimulate the momentum of entrepreneurship and enhance competitive advantages. }\end{array}$ \\
\hline
\end{tabular}

Table 5 indicates that, whether an individual can be qualified as an entrepreneur is determined and measured by whether his/her personal and professional characteristics, traits and capabilities are contributive to the development of business competitiveness. The feasibility of ideas, the availability/accessibility of resources, in conjunction with the technological and managerial skills and experiences - together, they determine an entrepreneur's qualification and capability that can be used as a baseline criteria to estimate and predict his/her likelihood of controlling risks and uncertainties, or, his/her chances of successful process of innovation and entrepreneurship. Note that, given the politically autocratic rather than democratic system in those developing countries like China, the capability of taking 
advantages of government interventions is the ultimate determinant, particularly in determining the affinitive relationship between ideas feasibility and resource availability or accessibility (Zhao \& Zhang, 2016; 2017).

\section{Distinguishing Chintrepreneurship from the Traditional Concept of Entrepreneurship}

Although, entrepreneurship have widely garnered recognition as the driving force propelling industrialization and economic development in developed economies, nevertheless, they have not earned their deserved-respect in those developing countries (Baumol et al., 2009; Bruton et al., 2010; Cumming \& Suret, 2011; Du et al., 2013; Kaldor, 1966; Leff, 1979; Ireland et al., 2003; Lu et al., 2013; Perkins et al., 2013; Rodrik \& Rosenzweig, 2010; Zahra et al., 2006). There exists a need to establish a theoretical framework to systematically rationalize the mechanism of how Chintrepreneurship has influenced China industrial development and economic growth (Zhao, 2016; 2017). The most controversial point is: whether Chintrepreneurship can be qualified and applied as a business model for both developed and developing economies (Ahlstrom, 2010; Audretsch et al., 2006; Butler et al., 2004), in terms of job creation (Phelps, 2013), poverty alleviation (Bruton et al., 2013), and social welfare as a whole. To this end, scholars posited that, to what degree entrepreneurship can contribute to economic development in developing countries is a fundamental question to be answered (Wong et al., 2005).

To understand the mechanism of Chintrepreneurship in China, the role of government intervention in incentivizing and facilitating ownership transformation, stimulating and enforcing industrial consolidation and privatization, while still maintaining the autocratic communist system, has been one of the dilemmatic wonders puzzling the contemporary practitioners and researchers (Li, 2006; Zhao \& Zhang, 2016; 2017). Correspondingly, how entrepreneurs in China have managed to survive in such a political environment has been widely researched topic (Chen et al., 2012; Kazanjian et al., 2002; Peng, 2006; Yang \& Li, 2008). To solve these pending puzzles, the rest of this paper focuses on the issues including, the dearth of private ownership right (POR), the government intervention (i.e.: Dual-Track System), regional and wealth disparities, and other related barriers that might be obstructive to the sustainability of Chintrepreneurship.

\subsection{Collectivism vs. Individualism: A Dilemma Sabotaging the Concept of Entrepreneurship}

It is suggested that, why and how, the rapidly emerged Chintrepreneurship can be incubated and nurtured in a politically autocratic, cronyism-oriented and collectivism-based system (China), should be treated as a theoretical question, fundamentally sabotaging or at least shaking the foundation of traditionally conceptualized framework that, only a politically democratic system can thrive the individualism-based entrepreneurship (Zhao, 2017). To this end, the collectivism-based Chintrepreneurship deserves to be incorporated into the neo-classic economic theory, in order to provide a new paradigm for those contemporary Western scholars and politicians to shake-off their status quo of skepticism in the face of emerging model of China-way of entrepreneurship. The constant growth of China GDP even in the downturn of global economy proves itself that, Chintrepreneurship is successful in terms of speed, scale and scope (Keane, 2007; Kynge, 2000), indicating that, in today's rapidly globalized and diversified environment, the government-led or the collectivism-based entrepreneurship may be more appropriate than the traditionally individualism-based entrepreneurship. Given that the wholeness is greater than the sum of pieces, it is plausible to rationalize why those globally competitive FDIs failed to compete with the government-supported indigenous enterprises in China (Zhao, 2016; 2017).

Empirical results suggested that, the contribution of entrepreneurship to economic growth tend to be country-specific (Zhang \& Stough, 2013). The impact of political and cultural systems on the mechanism of entrepreneurship must be carefully weighted and examined, in order to understand the emerging phenomena of entrepreneurship geminated from those developing economies like China - historically infused with the autocratic and cronyism oriented Confucianism (君君臣臣,父父子子), namely, let the king be the king, the courtier be the courtier, and let the father be the father, the son be the son (Zhao, 2016; 2017). In such an officialdom/superiors-will-dominated society, obedience is the core of political-social-cultural structure, obstructing free-thinking, transparent-communication and market-oriented entrepreneurship (Hall, 1981; Hofstede, 1994). Note that, when Americans think of entrepreneurs, they think of individuals like Bill Gates, Steve Jobs, Larry Page and Sergey Brin, technical geniuses who created huge business empires based upon their beliefs and practices of science, technology and innovation. In contrast, when people in China think of entrepreneurs, they think of people who have the courage to abandon the 'Golden Bowl' and start a small business to survive, rather than technological creativity and innovation. The reigning issue challenging entrepreneurs in China is how to take advantage of government policy to make profit. 'Who you know determines what you can do', may best rationalize the mechanism of entrepreneurship (Zhao, 2016). Understanding 
such a cronyism oriented political system may help solve the dilemmatic puzzle between collectivism and individualism in the formational and functional mechanism of entrepreneurship (Zhao \& Zhang, 2016; 2017).

\subsection{The Dearth of Private Ownership Right and the Development of Chintrepreneurship in China}

It is indeed the fact that, the overseas Chinese Diasporas are well-known for their entrepreneurial spirit around the Pacific Rim. However, entrepreneurship was virtually impossible in China for nearly 80 years of the $20^{\text {th }}$ century (Ahlstrom et al., 2004; Balazs, 1964; Landes, 1998; Pan, 1990). For half of the century, China was undergoing a period of warfare. From 1950s to 1970s, the country underwent a series of political, ideological and cultural turmoil and upheavals, such as land reforms, economic collectivization or nationalization and Cultural Revolution. Private Ownership Right (POR) and entrepreneurship became tabooed vocabularies, chastised and prohibited under the communist government system (Cooper, 2010; Harding, 1987; Nasar, 2012; Naughton, 1995; Rawski, 1989; Zhao, 2016; 2017). Even the intellectual property right (IPR) such as individuals' inventions was also defined as state owned property, confiscated from the original inventors, and offered them nominal reward as symbolic compensation without bargain (Balazs, 1964; Finley, 1965). Such a dearth of POR can be traced back to Confucianism, a hierarchical system, determining the inheritable privilege of properties assigned by the royal family to its government officials according to their respective rankings in the feudalistic past (Balazs, 1964; Ho, 1962), and by the mono-party control of communist government in the modern history. This is the root cause of China politically, socially, culturally and economically bureaucracy-cronyism oriented system, hindering indigenous proprietary innovations and entrepreneurship (Rosenberg \& Birdzell, 1986).

After the Communist took over in 1949, China adopted the former Soviet political-economic system. Entrepreneurship was completely prohibited, enterprises were forced to seek government approval prior to virtually everything they do (Rawski, 1989; Reynolds, 1982), managers forced to obtain government authorization, prior to every decision they make (Liu \& Wang, 1984). In a sense, entrepreneurship was completely wiped out from China political radar. However in 1978, when Deng Xiaoping took over the leadership and launched economic reforms, the country has been constantly experiencing the development of Chintrepreneurship and economic transformation, from a government planned economy, to a nascent but more like a hybrid market economy, from one of the poorest countries, to the $2^{\text {nd }}$ largest world economy (Harding, 1987; Huang, 2008; Yueh, 2013). In 2012, the registered SMEs exceeded approximately six million (Chen, 2006), and contributed to over 50\% of China GDP growth in addition to social welfare and poverty alleviation improvement (Huang, 2008; The Economist, 2009a; 2009b; The Economist, 2011). Therefore, understanding the footprint of Chintrepreneurship might provide experiences and directions, practically meaningful for other developing countries to pursue their catch-ups (Chen et al., 2012), and theoretically instructional for researchers to rationalize the respective impacts of the collectivism-based Beijing Consensus versus the individualism-based Washington Consensus on the mechanism of entrepreneurship (Zhao, 2016; 2017).

\subsection{The Government Intervention (Dual-Track System) and Regional and Wealth Disparities}

It is argued that, the geographically diversified social, cultural, ethnical and economic patterns may explain the original motif and purpose of government dual-track policy system, which was initiated by Deng Xiaoping to rapidly let a few people and regions to get rich first (Zhao \& Zhang, 2016). Dramatically, such a geographically discriminatory policy system has effectively caused a sharply contrasted economic imbalance between those selected regions (coastal cities such as Shenzhen, Shanghai, Xiamen, Dalian and those specifically zoned science and industrial parks, etc.), and authorized them with a series of exclusively privileged policies and treatments to move faster than the rest parts of China (Zhao \& Zhang, 2016). Empirical evidences also confirmed that, government dual-track policy system is the root-cause of both regional and wealth disparities, resulting from the differentiated development of innovation, entrepreneurship, industrial development, job creations, financial capital, human capital (knowledge and technology), input/output per capita, consuming market (population-led purchasing power), and infrastructural amenities (Zhang \& Stough, 2013).

Acknowledging the negative impact of government dual-track system on the formation of regional and wealth disparities, does not mean that its positive effect can be ignored. As a matter of fact, those firstly-initiated economic zones have indeed played their expected role in leading the nation' economic development. To this end, given the autocratic and cronyism-oriented nature of China government system, it is the political rather than the economic impact on the formation of an overall peculiarity of Chintrepreneurship. To some extent, without government dual-track policy, the rapid development of Chintrepreneurship would not be possible (Zhao \& Zhang, 2016). Some scholars claimed that entrepreneurs in private sectors must be more nimble to government policies, than those in SOEs in order to avoid or reduce political and institutional risks, and to capture entrepreneurial opportunities (Bruton \& Ahlstrom, 2003). In a sense, an ideological dilemma that, how such regional and wealth disparities have been fermented in a historically and still contemporarily self-declared socialist system, has become an emerging but 
seemingly embarrassing phenomenon sabotaging the traditionally democracy- and free-market dominated framework of entrepreneurship (Zhao, 2016; 2017). Therefore, a dialectic view is critical to objectively study and evaluate the role of government intervention in forming the peculiarity of Chintrepreneurship (See Table 6):

Table 6. Government Intervention, Entrepreneurship and Regional Disparity in China

\section{Characteristics of Economic Disparities}

When the open policy was ideologically disputed among those senior party leaders over the issue of private ownership, and given the low income, poor education, inefficient productivity, and size of rural population (55-75\% of China demography), the simple-minded rural people was selected as the sample or trial group to harness political divergence, avoid potential risk harmful to social stability, meanwhile initiate economic reform and Chintrepreneurship. By the mid-1990s, rural entrepreneurs accounted for 30-50 percent of China's private sectors, some of them have metamorphosed as globally reputed manufacturers such as Sanyang, the heavy industry equipment manufacturer, Wanxiang, an automobile component manufacturer, and Geely, the company that just acquired Volvo, just to name a few(Note 16). However, it is found that:

Rural - Purely relying on the price jack-up of agricultural products does not help to stimulate rural economy. Instead, transforming the low value-adding agricultural activities into the higher value-adding activities through industrialization would be an effective way to enhance rural productivity.

versus

Urban

- The bottom social stratum of rural people makes them a demographic group of nothing to lose, and hence, the faithful and loyal group to the mono-party autocratic communist leadership, the easiest group to be brainwashed, and the desperate group for any opportunities that may lead them to a better life. This is what makes the rural people the first generation of entrepreneurs in the early stage of China reforms, and still believed as the key force for China economic transition ahead (Note 17). To a certain extent, if without rural people engagement, Chintrepreneurship would not come this far(Note 18). The domestic consuming demand for agricultural products is far beyond China financial affordability for such a huge scale of imports. Therefore, agricultural industrialization to increase productivity through technological innovation seems to be the only option for China to continue its entrepreneurship, for today and for future.

Acknowledging the two types of entrepreneurship associated with their respective mechanism is critical. Type-I refers to Schumpeterian creative and destructive innovation oriented entrepreneurship, complying with the early-bird business strategy, requiring a vibrant market and competition system to nurture and fertile new business concepts/ideas and innovations. In contrast, Type-II is Keynesian government-led entrepreneurship, oft described as a catch-up strategy, and therefore, more realistic and feasible than the Type-I for emerging economies:

Political - The mechanism of Type-II entrepreneurship is determined politically rather than economically. Assuming the inevitable transition from autocratic to democratic is true, then, Type-II and Type-I may be interpreted as two phases of entrepreneurship complying with political evolution. The speed of this versus

Economical transition is determined by the speed of political and social democratization. For example, China is Type-II based entrepreneurship, which would not happen or survive, if without the let-go permission from its autocratic government (Zhao \& Zhang, 2016; 2017). Despite the achievement so far, whether China is able to transform from its government-oriented Type-II to market competition oriented Type-I, under the existing political system, is an imperative question. Answers to this question may help determine whether the Type-II can be used as a feasible and profitable model for other developing economies to follow.

In developing countries, the mechanism of entrepreneurship varies as a result of regionally differentiated government interventions (Malecki, 1993; Zhao, 2016; 2017):

Regional - It is argued that, innovation is constituted by the Schumpeterian rubric of creative and destructive force, driving the dynamism of capitalism, and determining the geographically differentiated formational patterns and mechanisms of entrepreneurship (Scott, 2006; Zhao, 2016; 2017). Empirical evidence also confirmed that, although lagged effect, regional disparity is inevitably and linearly associated with regional level of entrepreneurship, increased number of new start-up firms, and increased magnitude of job creation (Baptista, Escária \& Madruga, 2008). 
Table 6 indicates that, on the one hand, the path-dependent roadmap from government intervention to regional disparity is inevitable. On the other hand, entrepreneurship is far from a spontaneous or sporadic and self-relied activity. Instead, it is strictly disciplined and confined to a spatial-cum of political-social, institutional, cultural and economic conditions, susceptible to various kinds of breakdowns and disruptions (Zhao \& Zhang, 2016; 2017). It is argued that, given the autocratic nature of China political system, if without a political reform, whether China is able to transition from Type-II to Type-I entrepreneurship, from a catch-up economy to a knowledge-driven economy, in order to incubate some of its own Bill Gates and Steve Jobs, and to jump-start another economic leapfrog, seems to be an interesting question for future research (Zhao \& Zhang, 2017). As commented by Charles Zhang, the founder and CEO of China's second largest internet portal, Sohu.com:

“.......Without political reformation, there will be no fair market competition, no quality, no excellence, no employment opportunities, no stability, and no real rise of China...... Only by realizing maximum fairness, can those talented individuals and creative organizations emerge. ..... The government should stop protecting and supporting unfair competition." (Note 19)

\subsection{The Barriers Hindering the Sustainable Development of Chintrepreneurship}

Empirical evidences confirmed that, despite in the developed economies, the linear roadmap of entrepreneurship, business competitiveness and economic capability dominates the mainstream of literature, however, such a positive linearity is not significant in developing economies (Hector \& Rocha, 2004), and that the trajectory from entrepreneurship to industrial clusters and economic growth, is leveraged by regional technological capability of innovation, which serves as a platform to facilitate industrial transformation and corporate productivity (Feldman \& Yoon, 2012). For example, by comparing the diverged path of entrepreneurship between Silicon Valley, CA and Route 128, MA, the two global hubs of technological innovation in the IT-industries, some scholars found that, the sharply contrasted outcome between the two locations since the 1960s, may be attributed to their respectively differentiated path of industrial cultures, inter-firm relations and organizational capability of innovation (Kenney \& Burg, 1999).

In comparison, although the rapidly emerged industrial clusters (i.e.: science-technology parks) have played remarkable role in promoting the development of entrepreneurship in China (Zhao \& Zhang, 2016), however, scholars argued that, the differentiated formational patterns and mechanisms of entrepreneurship between the developing and the developed economies, especially with regard to the role of technological capability of innovation, has not received a deserved attention (Leff, 1978). Such a negligence is identified and claimed as the cause of conceptual elusiveness in the previous literature of entrepreneurship (Baumol, 2015), hindering the theoretical construction for the increasingly emerged entrepreneurial phenomena in those developing economies, in which, entrepreneurship is more needed than in those developed economies (Leff, 1978). In the face of these theoretically dubious and unsolved caveats, and given the technological constraints and political barriers, it is necessary to identify and understand the challenges and barriers that hinder the development of technological capability and discount the quality of entrepreneurship particularly in those developing economies like China (See Table 7):

Table 7 demonstrates the three constraints, challenging the mechanism of entrepreneurship in China. From political perspective, individual or organizational beliefs, goals and actions are restrained by a specific institutional setting (Scott, 2014). Therefore, the substantially deviated institutional system between China and Western societies (i.e. USA and European countries), must be taken into account in order to explain the variability of their respective mechanism of entrepreneurship (Ahlstrom et al., 2007). Note that, the government of China has also learnt and accumulated experiences, and endeavored to improve its institutional landscape and incentivize the development of entrepreneurship (Bruton et al., 2010). Since 1999, the government of China has launched a series of financial incentive packages, lifted its restrictions of private and informal finance and investment institutions, stimulated an unprecedented financial market expansion and diversification, and resulted in a rapid development of private venture capitals and investment firms. By 2010, there were 720 officially registered venture capital enterprises, operating 30 million RMB fund size on average of (Shen, 2011). Additionally, the government also launched the Inno-Fund program, to stimulate and incentivize a nationwide innovation and entrepreneurship (Allen et al., 2005; Newman et al., 2012). 
Table 7. Three Challenges Constraining the Development of Technological Capabilities in China

\begin{tabular}{|c|c|}
\hline & Characteristics \\
\hline $\begin{array}{l}\text { Financial } \\
\text { Capital } \\
\text { Constraint }\end{array}$ & $\begin{array}{l}\text { The lack of government trust is the most critical challenge depriving the eligibility of POEs/SMEs } \\
\text { from obtaining the government-controlled financial resources such as bank loans and credit } \\
\text { authorization (Cassar, 2004; Cong, 2009; Cooper et al., 1994; Florin, 2005; The Economist, 2011), } \\
\text { and hindering them from achieving competitive capabilities and advantages (Newman et al., 2012). }\end{array}$ \\
\hline $\begin{array}{l}\text { Human } \\
\text { Capital } \\
\text { Constraint }\end{array}$ & $\begin{array}{l}\text { The lack of a dedicated educational and professional training program leads to the lack of talents of } \\
\text { R\&Ds and technological innovation. Consequently, replicative or imitative innovations become the } \\
\text { only feasible option in China (Schmitz, 1989; Zhao, 2013;2014; 2016; 2017). }\end{array}$ \\
\hline
\end{tabular}

The lack of a democratically-based political, institutional and legal system hinders or constrains the development of a creative mechanism to encourage and incentivize technological capability:

- Government interventions (policies and regulations) hinder the ease of doing business and prevent the fair competition for entrepreneurial opportunities (Baumol, 1990; Chen et al.,

Political and Institutional Constraint 2012; Coase \& Wang, 2012). For instance, it takes entrepreneurs on average, to go through 13 procedures and 33 days to complete a single business registration, which only requires 5 procedures and 12 days in those OECD countries (World Bank, 2012).

- Government interventions (policies and regulations) are likely to cause the regional and wealth disparities (Ahlstrom et al., 2008; Cumming et al., 2009; Huang, 2010). For example, the dual-track policy is defined as a geographically discriminatory treatment between coastal regions and inland China (Zhao, 2016; 2017).

From the resource-based perspective, entrepreneurs in China have learnt and managed to navigate and take advantage of its government intervention system (Young et al., 2008). In a sense, what makes entrepreneurs in China differentiated from those in Western entrepreneurs is that, the top priority of China entrepreneurs is to network or connect with government system. In contrast, Western entrepreneurs generally focus on technological advancement and market expansion. However, it is unfortunate that, such a contrasted differentiation is either ignored or refuted by most of the contemporary scholars at present time (Ahlstrom \& Ding, 2014; Littunen, 2000; Sarasvathy, 2008; Shane \& Nicolaou, 2013; Tan, 2001; Van Praag \& Cramer, 2001; Wright et al., 2008; Xavier et al., 2013; Yang \& Zhang, 2012; Zhao \& Zhang, 2016; 2017). For this reason, the peculiarity of Chintrepreneurship deserves an in-depth research (See Table 8):

Table 8 illustrates the characteristics/attributes of entrepreneurs in China. Given that, entrepreneurship does not exist in a vacuum, and that, any entrepreneurial ideas and activities can be traced to an individual person, therefore, it is reasonable to hypothesize that, entrepreneurs must possess the capabilities (endogenous), sufficient enough not only to develop and strengthen their entrepreneurial momentum, but also to overcome the adversity of external conditions (exogenous). The combination of these characteristics/attributes constitutes the peculiarity or the precondition to determine whether an individual can be qualified as an agent of entrepreneurship in China (See Table 7 and 8). This is why that, some scholars contend that, despite the dogged effort of previous studies, the poverty of knowledge on the peculiar mechanism of Chintrepreneurship still remains as an academic challenge (Bruton et al., 2001; 2008; Haley et al., 2009; Hitt et al., 2004; Young et al., 2004; Zhao, 2016; 2017), hindering the cognitive development on: why and how, such a politically democratic and economically capitalistic and free market competition oriented entrepreneurship, has flourished in China, which is a historically inherited autocratic and cronyism oriented society? To this end, the significance of establishing a theoretical framework to explain and rationalize the peculiarity of Chintrepreneurship is far-reaching, especially for the knowledge development on the increasingly globalized and diversified trend and pattern of entrepreneurship (Lerner, 2009; Poldner, 2012; Yang \& Li, 2008; Zhao \& Zhang, 2016; 2017). 
Table 8. Personal Characteristics and Professional Attributes of Entrepreneurs in China

\begin{tabular}{ll}
\hline It is estimated that, the average age of entrepreneurs in China is in their early 30. About $44 \%$ \\
entrepreneurs are at the age of $25-34,57 \%$ around $18-34$ and less than $25 \%$ in the range of $45-64$, \\
indicating a diversified pattern with no significant difference of age (Xavier et al., 2013).
\end{tabular}

Entrepreneurs in China are generally well-educated. Nearly 32 percent hold bachelor degree, about

Education Level 27 percent are community college or equivalent level, 9 percent are secondary school or below, and 4.4 percent are the holders of master's degree or above (Yang \& Zhang, 2012).

Regional disparity leads to mass migration of talents and labors, from inland to coastal regions for

Migration jobs and higher wages, shaping the most phenomenal demographic characteristics of entrepreneurs. Overseas returnees with foreign knowledge and skills constitute another demographic characteristic of China entrepreneurs (Wright et al., 2008).

Over $80 \%$ of entrepreneurs have prior work experiences. Entrepreneurs in POEs tend to be more

Technical Skill innovative, proactive and productive, than those managers in SOEs (Tan, 2001; Zhao \& Zhang, 2016).

\begin{tabular}{ll}
\hline $\begin{array}{l}\text { Political } \\
\text { Networking } \\
\text { Skill }\end{array}$ & $\begin{array}{l}\text { Given the autocratic and cronyism-oriented political system, those successful entrepreneurs in } \\
\text { China are generally incubated and supported by, or at least associated with government system, } \\
\text { one way or another. Otherwise, no entrepreneurs would even survive (Zhao \& Zhang, 2016). }\end{array}$ \\
\hline $\begin{array}{l}\text { Problem-Solving } \\
\text { Skill }\end{array}$ & $\begin{array}{l}\text { Entrepreneurs in China possess stronger social networking aptitude but less technological skills in } \\
\text { problem solving than that of entrepreneurs elsewhere (Sarasvathy, 2008; Van Praag \& Cramer, } \\
\text { 2001). }\end{array}$ \\
$\begin{array}{l}\text { Risk-Taking } \\
\text { Propensity }\end{array}$ & $\begin{array}{l}\text { Entrepreneurs in China are more risk-taking-oriented than that of entrepreneurs elsewhere } \\
\text { (Littunen, 2000; Shane \& Nicolaou, 2013). This is so because they have nothing to lose (Zhao, } \\
\text { 2016). }\end{array}$ \\
\hline
\end{tabular}

\subsection{BRIDGE Model: An Adjusted Model of Entrepreneurship for Emerging Economies}

The lack or weak capability of transforming knowledge, from knowledge developers (academia) to knowledge users (industry) is perhaps, the most challenging issue, hindering the mechanism of entrepreneurship in many developing countries. Two noticeable reasons may explain this long-existing weakest link. The first is the lack of an effective government institutional system to guide and enforce the collaboration between research institutions and industrial entities. The second is the lack of technological capabilities to support the in-house R\&Ds and innovations. The direct consequence of the two weaknesses is the brain drain, namely, the migration of talented researchers and entrepreneurs, or, the key force of knowledge transformation. In response, a BRIDGE (Bridging Research, Industry, Development, Growth and Entrepreneurship) was designed and proposed as an entrepreneurial model, jointly initiated by African, Caribbean and Pacific Group of States (ACP) and European Union (EU). The BRIDGE Model aims to help developing countries to establish an effective and collaborated government intervention system to bridge the gap between research institutions and the consortia of companies, and to improve the efficient allocation, distribution and utilization of available and accessible resources across national border.

To make the BRIDGE Model robust, this paper argues that, government intervention must be treated as an indispensable and irreplaceable precondition to overcome the traditionally lagged process of value-transformation from knowledge (R\&Ds and innovations) to market values (salable products and/or services), to enforce the partnership between knowledge producers and industrial users, and to enhance the capability of entrepreneurship (See Figure 2): 


Information \& Data Collection
$\begin{aligned} & \text { Who needs the R\&Ds and } \\ & \text { innovation projects? }\end{aligned}$
$\begin{aligned} & \text { Who does the best for the } \\ & \text { targeted projects? }\end{aligned}$

Figure 2. BRIDGE Model for Developing Countries to Pursue Entrepreneurship

Figure 2 serves as a flow chart of a three-phased BRIDGE Model for the development of entrepreneurship. Government engagement determines the flow from collecting data and information and analyzing the resource availability and accessibility (Phase 1), through searching feasible and applicable cutting-edge knowledge (Phase 2), to designing and implementing an actionable and value-adding project plan (Phase 3).

Case Study 1: What makes Wenzhou the Dragon-Head of Entrepreneurship in China?

Wenzhou, a mid-sized city in Zhejiang province, is well-known as an entrepreneurial hub for the development of POEs in China. The great success of Wenzhou in incubating entrepreneurship during the past four decades may be summarized as the result of three reasons. Firstly, the government of Wenzhou is relatively less bureaucratic but more open-minded, more market-oriented and more supportive to the development of small business than the government of other cities in China. Secondly, entrepreneurs in Wenzhou are more market-oriented and more teamwork-oriented to exploit group advantages such as financial and marketing resources, than the entrepreneurs of other cities, wherein, they are more opportunistic oriented and more interested in Guanxi or personal networking with government systems. Thirdly, entrepreneurs in Wenzhou are mostly benefited from local Diasporas, who serve as the sources of financial investment and the outlets of import and export trade, and function as the BRIDGE, linking Wenzhou with both domestic and international markets. Put differently, it is the government intervention that enables Wenzhou to be the dragon head of entrepreneurship, contributing to the development of entrepreneurship in China.

\section{Case Study 2: What makes Taiwan an Entrepreneurial Pioneer?}

Ideologically, Taiwanese and people in mainland share an identical root of Chinese ethnical culture, which has been overwhelmingly dominated by Confucianism, stipulating that, the absolute authoritative and autocratic role of government should be unquestionable, untouchable and unshakable (Zhao \& Zhang, 2016). Such a cultural heritage has been infused in, inherited from, and carried on in the evolution of China society, impeding its development of democracy. On the contrary, Taiwan, after experiencing the 50-years' Japanese colonization and more than a half century American cultural influence, has transitioned into a semi-democratic and capitalistic system. From economic perspective, similar to (if not identical) the situation in mainland China that, properly taking advantage of government policy system is one of the best practices in nurturing the development of private enterprises and entrepreneurship in Taiwan. From business operation and strategic perspectives, it is reported that, SMEs in Taiwan have managed to swiftly adapt to and comply with policy-changes, and played a pivotal role in stimulating the development of manufacturing and high-tech industries, and meanwhile, facilitating the cost saving and latecomer strategies, leading to the rapidly advanced proprietary capability of innovation, constantly absorbed and accumulated from external technological and intellectual resources (Liu, 1998). To this end, government intervention is substantially the ultimate controller or adjustor in optimizing the interactions of political, social and economical settings, contributing to the overall economic development of both Taiwan, and even the pacific region. 


\section{Conclusions, Suggestions and Recommendations}

In spite of the dogged effort and great contribution of previous studies, an extensive literature review reveals their weakness, in measuring and evaluating the performance of the rapidly emerged mechanism of Chintrepreneurship, presenting an academic challenge for present and future researchers. Instead of being a spontaneous or sporadic and self-sufficient business activity, entrepreneurship is a path-dependent and susceptible to the diversified spatial-cum of political-social, institutional, cultural and economic conditions. Such a dynamic nature must be taken into account, both theoretically and practically, when discussing whether the government-oriented Chintrepreneurship can be smoothly transformed into a market-oriented and knowledge-driven entrepreneurship, and used as a catch-up model for other developing economies.This paper argues that, if properly designed, executed and institutionalized, government intervention can function as a critical controller/adjustor, influencing the tripartite relation of entrepreneurship, industrialization and economic growth. Having government intervention integrated into the measurement of entrepreneurship may not only help to explain the ideological and theoretical dilemma of why and how the traditionally defined democratic, capitalistic and free-market dominated entrepreneurship has thrived from the self-declared communist and socialist China, but also help to rationalize the critical need to establish a dialectic view to objectively study the role of government intervention in forming the peculiarity of Chintrepreneurship.

It must be emphasized that, given the autocratic nature of China political system, government intervention is indisputably the root cause of the geographically and economically divided haves and have-nots (regional disparity and wealth disparity). On the one hand, such a divide itself emerged and coexisted in the self-declared communist China sabotages and chastises the ideological foundation of communism. On the other hand, the success of Chintrepreneurship and its contribution to economic growth, achieved through the leadership of China communist government, suffices to prove that, regardless of political -isms or ideological doctrines of any kind, only those able to create and advance human welfare deserve to be selected in the course of human history. Following this line of reasoning, entrepreneurs in private sectors must be more nimble to government policies than those in SOEs, in order to minimize political and institutional risks, while maximize the benefit of entrepreneurship. To this end, what measurements should be established to evaluate and qualify an individual as an agent of entrepreneurship, and used to distinguish the collectivism-based Chintreprenership in China from the individualism-based entrepreneurship in Western societies, may be the theoretical priority for present and future researchers, in order to re-establish a holistic mechanism of entrepreneurship that is applicable to the dynamically globalized and diversified business environment.

Last but not least, until 2013, the fifth generation of China leadership headed by Xi Junping embarked a political reform centered by the movement of anti-corruption and anti-cronyism, stirring up an intensive debate within the communist ruling system. The opposition side (conservatism) argued that, it is superfluous, harmful and risky, jeopardizing the vested interests of communist party and the national priority of political stability. Notwithstanding, it is reasonable to expect that, the ongoing political reform may serve to recover the economic sluggish and the mired financial distress both domestically and internationally, and meanwhile, provide feasible solutions for the government-led Chintrepreneurship to overcome the encountered barriers and continue to stimulate China economy to grow. Following this logic, this paper proposes that, to prevent contemporary scholars and practitioners from continuously misidentifying and misinterpreting the emerging economic and business phenomena, especially from those developing economies, whether the government-led Chintrepreneurship should be confined to the traditionally inherited theoretical boxes of Schumpeterianism and Keynesianism, whether it is applicable as a catch-up model, and whether the observed problematic side-effects (ex.: regional and wealth disparities) can be weighted as a worthy tradeoff - all is determined by, whether government intervention can be systematically integrated into an entrepreneurial model, namely, the BRIDGE model to enrich the theoretical framework of entrepreneurship.

\section{Acknowledgements}

Many thanks must be extended to those Chinese scholars, policy consultants, business executives and involved interviewees for generously sharing their constructive and instructive thoughts, opinions, without which, this paper would not be able to cover the depth and scope. As always, it is thankful to the journal reviewers for their comments, suggestions and their time spent.

\section{References}

Abzug, R., Simonoff, J., \& Ahlstrom D (2000). Nonprofits as large employers: A city-level geographical inquiry. 
Nonprofit and Voluntary Sector Quarterly, 29(3), 455-470. https://doi.org/10.1177/0899764000293006

Ahlstrom, D. (2010). Innovation and growth: How business contributes to society. Academy of Management Perspectives, 24(3), 11-24. https://doi.org/10.5465/AMP.2010.52842948

Ahlstrom, D., \& Ding, Z. (2014). Entrepreneurship in China: An Overview. International Small Business Journal, 32(6), 610-618. https://doi.org/10.1177/0266242613517913

Ahlstrom, D., Bruton, G.D., \& Yeh, K.S. (2007). Venture capital in China: Past, present and future. Asia Pacific Journal of Management, 24(3), 247-268. https://doi.org/10.1007/s10490-006-9032-1

Ahlstrom, D., Bruton, G.D., \& Yeh, K.S. (2008). Private firms in China: Building legitimacy in an emerging economy. Journal of World Business, 43(4), 385-399. https://doi.org/10.1016/j.jwb.2008.03.001

Ahlstrom, D., Young, M.N., \& Chan, E.S. (2004). Facing constraints to growth? Overseas Chinese entrepreneurs and traditional business practices in East Asia. Asia Pacific Journal of Management, 18(3), 263-273. https://doi.org/10.1023/B:APJM.0000036463.20310.de

Allen, F., Qian, J., \& Qian, M. (2005). Law, finance, and economic growth in China. Journal of Financial Economics, 77(1), 57-116. https://doi.org/10.1016/j.jfineco.2004.06.010

Audretsch, D.B., \& Thurik, R. (2001). Linking Entrepreneurship to Growth. OECD Directorate for Science, Technology and Industry (Working Paper). Pearson Prentice-Hall. Upper Saddle River, NJ. USA. https://doi.org/10.1787/736170038056

Audretsch, D.B., Keilbach, M.C., \& Lehmann, E.E. (2006). Entrepreneurship and Economic Growth. Oxford: Oxford University Press. https://doi.org/10.1093/acprof:oso/9780195183511.001.0001

Balazs, E. (1964). Chinese Civilization and Bureaucracy: Variations on a Theme. New Haven, CT: Yale University Press.

Barreto, H. (1989). The Entrepreneur in Microeconomic Theory: Disappearance and Explanation. London: Routledge.

Baumol, W. J. (2015). Entrepreneurship: Productive, Unproductive and Destructive. Swiss Journal of Economics \& Statistics, 123(5), 415-423.

Baumol, W.J. (1968). Entrepreneurship in Economic Theory. American Economic Review, 58(2), 64-71.

Baumol, W.J. (1990). Entrepreneurship: Productive, unproductive and destructive. Journal of Political Economy, 98(5), 893-921. https://doi.org/10.1086/261712

Baumol, W.J. (1993). Formal entrepreneurship theory in economics: Existence and Bounds Journal of Business Venturing, 8(3), 197-210. https://doi.org/10.1016/0883-9026(93)90027-3

Baumol, W.J., Litan, R.E., \& Schramm, C.J. (2009). Good Capitalism, Bad Capitalism and the Economics of Growth and Prosperity. New Haven, CT: Yale University Press.

Birch, D.L. (1979). The Job Generation Process. Cambridge, MA: MIT Program on Neighborhood and Regional Change.

Boettke, P.J., \& Coyne, C.J. (2003). Entrepreneurship and Development: Cause or Consequence? Austrian Economics and Entrepreneurial Studies, 6, 67 - 87. https://doi.org/10.1016/S1529-2134(03)06005-8

Bruton, G.D., \& Ahlstrom, D. (2003). An institutional view of China's venture capital industry: Explaining the differences between China and the West. Journal of Business Venturing, 18(2), 233-259. https://doi.org/10.1016/S0883-9026(02)00079-4

Bruton, G.D., Ahlstrom, D., \& Li, H. (2010). Institutional theory and entrepreneurship: Where are we now and where do we need to move in the future? Entrepreneurship Theory and Practice, 34(3), 421-440. https://doi.org/10.1111/j.1540-6520.2010.00390.x

Bruton, G.D., Ahlstrom, D., \& Obloj, K. (2008). Entrepreneurship in emerging economies: Where are we today and where should the research go in the future? Entrepreneurship Theory and Practice, 32(1), 1-14. https://doi.org/10.1111/j.1540-6520.2007.00213.x

Bruton, G.D., Ahlstrom, D., \& Wan, JCC. (2001). Turnaround success of large and midsize Chinese-owned firms in Hong Kong and Thailand. Journal of World Business, 36(2), 146-165. https://doi.org/10.1016/S1090-9516(01)00047-5 
Bruton, G.D., Ketchen, D.J., \& Ireland, R.D. (2013). Entrepreneurship as a solution to poverty. Journal of Business Venturing, 28(6), 683-689. https://doi.org/10.1016/j.jbusvent.2013.05.002

Butler, J.E., Ko, S., \& Chamornmarn, W. (2004). Asian entrepreneurship research. In: Leung K and White S (eds.), Handbook of Asian Management. New York: Kluwer, pp.207-243. https://doi.org/10.1007/1-4020-7932-X_7

Carree, M., \& Thurik, R. (1998). Small firms and economic growth in Europe. Atlantic Economic Journal, 26(2), 137 -146. https://doi.org/10.1007/BF02299356

Carree, M., \& Thurik, R. (2002). The Impact of Entrepreneurship on Economic Growth. In Zoltan Acs and David B. Audretsch (2003), International Handbook of Entrepreneurship Research, Boston/Dordrecht: Kluwer Academic Publishers.

Cassar, G. (2004). The financing of business start-ups. Journal of Business Venturing, 19(2), 261-283. https://doi.org/10.1016/S0883-9026(03)00029-6

Chen, J. (2006). Development of Chinese small and medium-sized enterprises. Journal of Small Business and Enterprise Development, 13(2), 140-147. https://doi.org/10.1108/14626000610665854

Chen, Z., Sun, Y., \&vNewman, A. (2012). Entrepreneurs, organizational members, political participation and preferential treatment: Evidence from China. International Small Business Journal, 30(8), 873-889. https://doi.org/10.1177/0266242611407534

Coase, R.H. (1937). The Nature of the Firm. Economica, New Series, 4(16), 386-405. https://doi.org/10.1111/j.1468-0335.1937.tb00002.x

Coase, R.H., \& Wang, N. (2012). How China Became Capitalist. New York: Palgrave Macmillan. https://doi.org/10.1057/9781137019370

Cong, J. (2009). Chinese informal financial systems and economic growth: A case study of China's small and medium enterprises. Public Policy Review, 5(1), 63-88.

Cooper, A. (2010). Entrepreneurship: The past, the present, the future. In: Acs ZJ and Audretsch DB (eds.), Handbook of Entrepreneurship Research: An Interdisciplinary Survey and Introduction. Boston, MA: Kluwer Academic Publishers, pp.21-36.

Cumming, D.J., \& Suret, J.M. (2011). Entrepreneurial finance and venture capital markets. European Financial Management, 17(3), 420-422. https://doi.org/10.1111/j.1468-036X.2011.00610.x

Dejardin, M. (2000). Entrepreneurship and Economic Growth: An Obvious Conjunction? Namur, Belgium: University of Namur.

Drucker, P.F. (1985). Innovation \& Entrepreneurship Practices and Principles. Publisher: Harper \& Row, New York, U.S.A. ISBN-10: 0060112484

Du, J., Guariglia, A., \& Newman, A. (2013). Do social capital building strategies influence the financing behavior of Chinese private small and medium-sized enterprises? Entrepreneurship Theory and Practice. Epub ahead of print, 7 July 2013. https://doi.org/10.1111/etap.12051

Educational \& Development of an Entrepreneurial Culture Unit (EDECU) (2002). Research on the Impact of EMPRETEC in Brazil. Rio de Janeiro: SEBRAE.

Egai, N. A. (2008). Entrepreneurial development: for increased competitiveness and Business growth. Institute of Chartered Economists of Nigeria's Seminar'.

EMPRETEC. (2004). Entrepreneurship and Economic Development: The EMPRETEC Showcase. United Nations Conference on Trade and Development, Geneva. The Report is accessible Online at: http://unctad.org/en/Docs/webiteteb20043_en.pdf.

Feldman, M.P., \& Yoon, J.W. (2012). An empirical test for general purpose technology: an examination of the Cohen-Boyer rDNA technology. Industrial and Corporate Change, 21(2), 249-275. https://doi.org/10.1093/icc/dtr040

Finley, M.I. (1965). Technical innovation and economic progress in the ancient world. Economic History Review, 18(1), 29-45. https://doi.org/10.2307/2591872

Florin, J. (2005). Is venture capital worth it? Effects on firm performance and founder returns. Journal of Business Venturing, 20(1), 113-135. https://doi.org/10.1016/j.jbusvent.2003.12.006 
Friijs, Christian, Thomas Paulsson and Charlie Karlsson (2002). Entrepreneurship and Economic Growth: A Critical Review of Empirical and Theoretical Research. Östersund, Sweden: Institutet för tillväxtpolitiska studier.

Galbraith, J.K. (1967). The New Industrial State. Boston, MA: Houghton Mifflin.

Haley, G.T., Haley, U.C.V., \& Tan, C.T. (2009). New Asian Emperors: The Business Strategies of the Overseas Chinese. New York: Wiley.

Hall, E. T. (1981). Beyond Culture. New York: Doubleday.

Haltiwanger, J., Jarmin, R.S., \& Miranda, J. (2011). Who Creates Jobs? Small vs. Large vs. Young. Washington, DC: U.S. Census Bureau.

Harding, H. (1987). China's Second Revolution: Reform after Mao. Washington, DC: Brookings Institute.

Hector O., \& Rocha, H.O. (2004). Entrepreneurship and Development: The Role of Clusters. Small Business Economics, 23(5), 363-400. https://doi.org/10.1007/s11187-004-3991-8

Hisrich, R. D., \& Peter, M. P. (2002). Entrepreneurship. Singapore: McGraw-Hill.

Hitt, M.A., Ahlstrom, D., \& Dacin, M.T. (2004). The institutional effects on strategic alliance partner selection in transition economies: China versus Russia. Organization Science 15(2), 173-185. https://doi.org/10.1287/orsc. 1030.0045

Ho, P.T. (1962). The Ladder of Success in Imperial China: Aspects of Social Mobility, 1368-1911. New York: Columbia University Press.

Hofstede, G. (1994). Cultures and Organizations - Intercultural Cooperation and its Importance for Survival. London: Harper Collins Business.

Huang, Y. (2008). Capitalism with Chinese Characteristics. Cambridge: Cambridge University Press. https://doi.org/10.1017/CBO9780511754210

Huang, Y. (2010). Debating China's economic growth: The Beijing Consensus or the Washington Consensus? Academy of Management Perspectives, 24(2), 31-47. https://doi.org/10.5465/AMP.2010.51827774

Ireland, R.D., Hitt, M.A., \& Sirmon, D.G. (2003). A model of strategic entrepreneurship: The construct and its dimensions. Journal of Management, 29(6), 963-989. https://doi.org/10.1016/S0149-2063(03)00086-2

Jääskeläinen, M. (2000). Entrepreneurship and Economic Growth. Helsinki: Institute of Strategy and International Business.

Kaldor, N. (1966). Strategic Factors in Economic Development. New York: New York State School of Industrial and Labour Relations.

Kantis, H., Masahiko I., \& Masahiko, K. (2002). Entrepreneurship in Emerging Economies: The Creation and Development of New Firms in Latin America and East Asia. Washington, DC: Inter-American Development Bank.

Kazanjian, R., Drazin, R., \& Glynn, M. (2002). Implementing strategies for corporate entrepreneurship: A knowledge-based perspective. In: Hitt M, Ireland R, Camp S, et al. (eds.), Strategic Entrepreneurship: Creating a New Mindset. Oxford: Blackwell, pp.173-200.

Keane, M. (2007). Created in China: The great new leap forward. New York: Rutledge.

Kenney, M. \& Burg, U von. (1999). Technology, entrepreneurship and path dependence: industrial clustering in Silicon Valley and Route 128. Industrial and Corporate Change, 8(1), 67-103. https://doi.org/10.1093/icc/8.1.67

Keynes, J.M. (1920). The Economic Consequences of the Peace. New York: Harcourt Brace.

Klofsten, M., \& Jones-Evans, D. (2000). Comparing Academic Entrepreneurship in Europe - The Case of Sweden and Ireland. Small Business Economics, 14(4), 299-309. https://doi.org/10.1023/A:1008184601282

Kynge, J. (2000). China Plans Support for Private Sector. Financial Times, January $5^{\text {th }}, 2000$.

Landes, D.S. (1998). The Wealth and Poverty of Nations: Why Some are So Rich and Some So Poor. New York: W.W. Norton.

Leff, N.H. (1978). Industrial Organization and Entrepreneurship in the Developing Countries: The Economic Groups. Economic Development and Cultural Change, 26(4), 661-675. https://doi.org/10.1086/451052 
Leff, N.H. (1979). Entrepreneurship and economic development: The problem revisited. Journal of Economic Literature, 17(1), 46-64.

Lerner, J. (2009). Boulevard of Broken Dreams: Why Public Efforts to Boost Entrepreneurship and Venture Capital Have Failed - and What to Do About it. Princeton, NJ: Princeton University Press. https://doi.org/10.1515/9781400831630

Li, H. (ed.) (2006). Growth of New Technology Ventures in China's Emerging Market. Cheltenham: Edward Elgar.

Littunen, H. (2000). Entrepreneurship and the characteristics of the entrepreneurial personality. International Journal of Entrepreneurial Behavior and Research, 6(6), 295-310. https://doi.org/10.1108/13552550010362741

Liu, G., \& Wang, R. (1984). Restructuring of the economy. In: Yu G (ed.), China’s Socialist Modernization. Beijing: Foreign Languages Press, pp.89-97. https://doi.org/10.1109/17.728575

Liu, S. (1998). Industrial development and structural adaptation in Taiwan: some issues of learned entrepreneurship. Engineering Management, IEEE, 45(4), 338-348. https://doi.org/10.1109/17.728575

Lu, Y., Au, K., \& Peng, M.W. (2013). Strategic management in private and family business. Asia Pacific Journal of Management, 30(3), 633-639. https://doi.org/10.1007/s10490-013-9359-3

Malecki, E.J. (1993). Entrepreneurship in Regional and Local Development. International Regional Science Review, 16(1-2), 119-153. https://doi.org/10.1177/016001769401600107

Marris, P., \& Somerset, A. (1971). African businessmen. A study of entrepreneurship and development in Kenya. London, UK: Routledge \& Kegan Paul. ISBN-10: 0710069588, pp.1-188.

McClelland, D.C. (1961). The Achieving Society. Princeton, NJ: Van Nostrand. https://doi.org/10.1037/14359-000

McClelland, D.C. (1965). Toward a theory of motive acquisition. American Psychologist, 20(5), 321-333. https://doi.org/10.1037/h0022225

McCraw, T.K. (2010). Prophet of Innovation: Joseph Schumpeter and Creative Destruction. Cambridge, MA: Belknap Press. https://doi.org/10.4159/9780674040779

Medoff, J., \& Birch, D. (1994). In gazelles. In: Solmon LC and Levenson AR (eds.), Labor Markets, Employment Policy and Job Creation. Boulder, CO: Westview Press, pp.159-168.

Müller, S.L., \& Abisya, S.T. (2001). Culture and entrepreneurial potential: A nine-country study of locus of control and innovativeness. Journal of Business Venturing, 16(1), 51-75. https://doi.org/10.1016/S0883-9026(99)00039-7

Nasar, S. (2012). Grand Pursuit: The Story of Economic Genius. New York: Simon \& Schuster.

Naughton, B. (1995). Growing Out of the Plan: Chinese Economic Reform, 1978-1993. New York: Cambridge University Press. https://doi.org/10.1017/CBO9780511664335

Newman, A., Gunnessee, S., \& Hilton, B. (2012). The applicability of financial theories of capital structure to the Chinese cultural context: A study of privately-owned SMEs. International Small Business Journal, 30(1), 65-83. https://doi.org/10.1177/0266242610370977

Nickell, S.J. (1996). Competition and corporate performance. Journal of Political Economy 104(4), 724-746. https://doi.org/10.1086/262040

Nickell, S.J., Daphne, N., \& Neil D. (1997). What makes firms perform well? European Economic Review, 41, 783-796. https://doi.org/10.1016/S0014-2921(97)00037-8

Nwaobi, G.C. (2012). Business Entrepreneurship (Technopreneurship): Evolution and Practice. Social Science Research Network. http://dx.doi.org/10.2139/ssrn.2044854.

Ogilvie, S. (2011). Institutions and European Trade: Merchant Guilds, 1000-1800. Cambridge: Cambridge University Press. https://doi.org/10.1017/CBO9780511974410

Organization for Economic Co-operation and Development (OECD). (1998). Fostering Entrepreneurship. Paris: OECD.

Organization for Economic Co-operation and Development (OECD). (2002). Benchmarking: Fostering Firms Creation and Entrepreneurship. Paris: OECD Directorate for Science, Technology and Industry.

Pan, L. (1990). Sons of the Yellow Emperor: A History of the Chinese Diaspora. Boston, MA: Little, Brown. 
Peng, M.W. (2006). How do entrepreneurs create wealth in transition economies? In Li H (ed.), Growth of New Technology Ventures in China's Emerging Market. Cheltenham: Edward Elgar, pp.87-111.

Peretto, P.F. (1999). Industrial development, technological change, and long-run growth. Journal of Development Economics, 59, 389-417. https://doi.org/10.1016/S0304-3878(99)00018-8

Perkins, D.H., Radelet, S., \& Lindauer, D.L. (2013). Economics of Development ( $7^{\text {th }}$ ed). New York: W.W. Norton.

Phelps, E.S. (2013). Mass Flourishing: How Grassroots Innovation Created Jobs, Challenge and Change. Princeton, NJ: Princeton University Press. https://doi.org/10.1515/9781400848294

Pirich, A. (2001). An interface between entrepreneurship and innovation: New Zealand SMEs perspective. Paper prepared for the 2001 DRUID Conference, Aalborg, Denmark.

Poldner, K. (2012). Omnisensoring social entrepreneurship: nine practices to construct ventures in a glocal economy. Managing in A Global Economy XIV Global Web of Knowledge. Downloaded on Dec. 16, 2016 at: https://www.alexandria.unisg.ch/export/PDF/publicazione/211544.pdf.

Porter, M.E. (1990). The Competitive Advantage of Nations. New York: Free Press. https://doi.org/10.1007/978-1-349-11336-1

Rawski, T. (1989). Economic Growth in Prewar China. Berkeley. CA: University of California Press.

Reynolds, B.L. (1982). Reform in Chinese industrial management: An empirical report. In: Joint Economic Committee, Congress of the United States (ed.), China under the Four Modernizations: Selected Papers, Part I. Washington, DC: U.S. Government Printing Office, pp.119-137.

Reynolds, P.D., William, D.B., Erkko, A., Larry, W.C., \& Michael, H. (2002). Global Entrepreneurship Monitor 2002 Executive Report. Wellesley, MA/London: Babson College/London Business School.

Rodrik, D., \& Rosenzweig, M.R. (eds) (2010). Handbook of Development Economics, Vol. 5. Kidlington: North Holland/Elsevier.

Rosenberg, N., \& Birdzell, L.E. (1986). How the West Grew Rich: The Economic Transformation of the Industrial World. New York: Basic Books.

Sarasvathy, S.D. (2008). Effectuation: Elements of Entrepreneurial Expertise. Cheltenham: Edward Elgar. https://doi.org/10.4337/9781848440197

Schmitz, J.A. (1989). Imitation, entrepreneurship and long-run growth. Journal of Political Economy, 97(3), 721-739. https://doi.org/10.1086/261624

Schumpeter, J. A. (1934). The Theory of Economic Development: An inquiry into profits, capital, credit, interest, and the business cycle. University of Illinois at Urbana-Champaign's Academy for Entrepreneurial Leadership Historical Research Reference in Entrepreneurship. The paper was posted online on 11/04/2009, accessible at: http://papers.ssrn.com/sol3/papers.cfm?abstract_id $=1496199 \&$.

Schumpeter, J. A. (2008[1942]). From Capitalism, Socialism and Democracy. $3^{\text {rd }}$ ed., Routledge. The $1^{\text {st }}$ edition was published in 1942. Re-edited in 1975 as "From Capitalism, Socialism and Democracy", published by Harper and Brothers: New York, pp. 82-85.

Schumpeter, J.A. (1942). Capitalism, Socialism and Democracy( $3^{\text {rd }}$ ed.). New York: Harper \& Brothers,

Scott, A.J. (2006). Entrepreneurship, Innovation and Industrial Development: Geography and the Creative Field Revisited. Small Business Economics, 26(1), 1-24. https://doi.org/10.1007/s11187-004-6493-9

Scott, W.R. (2014). Institutions and Organizations: Ideas, Interests and Identities. Thousand Oaks, CA: Sage.

Shane, S.A., \& Nicolaou, N. (2013). The genetics of entrepreneurial performance. International Small Business Journal, 31(5), 473-495. https://doi.org/10.1177/0266242613485767

Shen, W.J. (2011). The status quo of venture capital in China. Available at: http://www.us-china-cerc.org/participants/downloads/IPWorkshop_SHEN_Wenjing.pdf $\quad$ (accessed 15 September 2013).

Stevenson, H. H. (1983). A Perspective on Entrepreneurship. Harvard Business School

Stevenson, H. H. (2000). Why Entrepreneurship Has Won! Coleman White Paper, Addressed at USASBE Plenary Conference Held on February $17^{\text {th }}$, 2000. Retrieved March 20 2014 fromhttp://www.unm.edu/ asalazar/Kauffman/Entrep_research/e_won.pdf. 
Stevenson, H.H., \& Gumpert, D.E. (1985). The Heart of Entrepreneurship. HBR, 63(2): 85-94. Accessed at: https://hbr.org/1985/03/the-heart-of-entrepreneurship.

Tan, J. (2001). Innovation and risk-taking in a transitional economy: A comparative study of Chinese managers and entrepreneurs. Journal of Business Venturing, 16(4), 359-376. https://doi.org/10.1016/S0883-9026(99)00056-7

The Economist, (2009a). Global heroes: A special report on entrepreneurship, 14 March, 1.

The Economist, (2009b). Burgeoning bourgeoisie: A special report on the new middle classes in emerging markets, 14 February, 1.

The Economist, (2011). Entrepreneurship in China: Let a million flowers bloom, 10 March, 79.

Thurik, R., \& Wennekers, S. (2001). A Note on Entrepreneurship, Small Business and Economic Growth. Rotterdam: Erasmus Research Institute of Management Report Series.

Torres, A., Bijmolt, T.H., Tribó, J.A., \& Verhoef, P. (2012). Generating global brand equity through corporate social responsibility to key stakeholders. International Journal of Research in Marketing, 29(2012), 13-24. https://doi.org/10.1016/j.jiresmar.2011.10.002

UNIDO. (1999). 'Report'. Retrieved Feb. 24, 2013from www.unido.org

Van de Ven, A.H. (1993). The development of an infrastructure for entrepreneurship. Journal of Business Venturing, 8(3), 211-230. http://dx.doi.org/10.1016/0883-9026(93)90028-4

Van Praag, C., \& Cramer, J. (2001). The roots of entrepreneurship and labour demand: Individual ability and low risk aversion. Economica, 68(269), 45-62. https://doi.org/10.1111/1468-0335.00232

Wennekers, S., \& Thurik, R. (1999). Linking entrepreneurship and economic growth. Small Business Economics, 13, 27-55. https://doi.org/10.1023/A:1008063200484

Wong, P.K., Ho, Y.P., \& Autio, E. (2005). Entrepreneurship, innovation and economic growth: Evidence from GEM data. Small Business Economics, 24(3), 335-350. https://doi.org/10.1007/s11187-005-2000-1

World Bank Group, (2012). Doing Business 2013: Smarter Regulations for Small and Medium-Size Enterprises. Washington, DC: World Bank Publications.

Wright, M., Liu, X., \& Buck T. (2008). Returnee entrepreneurs, science park location choice and performance: An analysis of high-technology SMEs in China. Entrepreneurship, Theory and Practice, 32(1), 131-155. https://doi.org/10.1111/j.1540-6520.2007.00219.x

Xavier, S.R., Kelley, D., \& Kew, J. (2013). Global Entrepreneurship Monitor, 2012 Global Report. London: Global Entrepreneurship Research Association. ISBN: 9781939242044. Retrieved Nov. 08, 2016 from https://www.mendeley.com/research-papers/global-entrepreneurship-monitor-2013-global-report-28/

Yang, J., \& Zhang, Y.L. (2012). Who are nascent entrepreneurs and how do they start up new ventures? unpublished working paper, Nankai University, China.

Yang, J.Y., \& Li, J. (2008). The development of entrepreneurship in China. Asia Pacific Journal of Management, 25(2), 335-359. https://doi.org/10.1007/s10490-007-9078-8

Yiu, D.W., \& Lau, C. M. (2008). Corporate Entrepreneurship as Resource Capital Configuration in Emerging Market Firms. Entrepreneurship Theory and Practice, 32(1), 37-57. https://doi.org/10.1111/j.1540-6520.2007.00215.x

Young, M.N., Ahlstrom, D., \& Bruton, G.D. (2004). The globalization of corporate governance in East Asia: The 'transnational' solution. Management International Review, 44(2), 31-50. https://doi.org/10.1007/978-3-322-90997-8_3

Young, M.N., Peng, M.W., Ahlstrom, D., Bruton, G.D., \& Jiang, Y. (2008). Corporate governance in emerging economies: A review of the Principal-Principal perspective. Journal of Management Studies, 45(1), 196-220. https://doi.org/10.1111/j.1467-6486.2007.00752.x

Yueh, L. (2013). China's Growth: The Making of an Economic Superpower. New York: Oxford University Press. https://doi.org/10.1093/acprof:oso/9780199205783.001.0001

Zahra, S.A., Sapienza, H.J., \& Davidsson, P. (2006). Entrepreneurship and dynamic capabilities: A review, model and research agenda. Journal of Management Studies, 43(4), 917-955. https://doi.org/10.1111/j.1467-6486.2006.00616.x

Zhang, T., \& Stough, R.R. (2013). Entrepreneurship and Economic Growth in China. World Scientific. ISBN: 
978-981-4273-36-7. https://doi.org/10.1142/7296

Zhao, J. (2012). The Role of CAD Application in Open Innovation Model: Innovation Technology in the Chinese Shipbuilding Industry. International Journal of Business Innovation and Research (IJBIR), 6(6), 698-719. https://doi.org/10.1504/IJBIR.2012.049492

Zhao, J. (2013). A Cognitive Discussion on Shanzhai: An Emerging Innovation Model. Global Advanced Research Journal of Management and Business Studies (GARJMBS), 2(3), 137-153.

Zhao, J. (2014). An Argument on the Existing Framework of Entrepreneurship - Shanzhai: An Emerging Entrepreneurial Model. International Journal of Economics, Commerce and Management (IJECM), 2(5), 1 51.

Zhao, J. (2016). A Conceptual Discussion on the Peculiarity of Doing Business in China - A Framework Extracted from Critical Review of HBSP China Case Studies. International Journal of Economics, Commerce and Management (IJECM), 4(4), 411 - 452.

Zhao, J. (2017). Chintrepreneurship as a Catch-up Model for Developing Economies: A Tripartite Framework of Government Intervention, Entrepreneurship and Economic Development. International Journal of Economics, Commerce and Management (IJECM), 5(6), 245-273.

Zhao, J. (2017). Government Intervention, Seedling Approach, and Global Networks: A Modeling for the China-way of Entrepreneurship. International Journal of Economics, Commerce and Management (IJECM), 5(2), 1-55.

Zhao, J., \& Zhang, B. (2016). A Theoretical Framework on the Peculiarity of Doing Business in China-An Extensive Review on HBSP China Business Cases. Modern Management Science \& Engineering (MMSE), 4(1), $62-100$.

Zhao, J., \& Zhang, B. (2017). Chintrepreneurship - The China-way of Entrepreneurship: Government Intervention, Seedling Approach - A Network-based Model of Entrepreneurship. Management and Organizational Studies, 4(1), 30-66. https://doi.org/10.5430/mos.v4n1p30

\section{Notes}

Note 1. Posted by The Economist, Special Report: Entrepreneurship, on $12^{\text {th }}$ March 2009 at: http://www.economist.com/node/13216025?story_id=13216025, downloaded on May $5^{\text {th }}, 2014$.

Note 2. An informal interview held on July $2^{\text {nd }}, 2013$, with Professor Qian, who is a professor of macro-economy at China RenMin University.

Note 3. Excerpted from a Special Report: Entrepreneurship from The Economist. The Report was posted on $12^{\text {th }}$ March, 2009, and titled as Global Heroes, accessible at http://www.economist.com/node/13216025.

Note 4. Research and Ideas, The two faces of Entrepreneurship, part one: ..... The article was posted on the $19^{\text {th }}$ of July of 2006, accessible at: http://research.wpcarey.asu.edu/economics/the-two-faces-of-entrepreneurship-part-one-replicative-entrepreneurs-ser ve-growing-population/.

Note 5. Accessible at : http://www.gemconsortium.org/country-profile/99.

Note 6. Global Entrepreneurship Monitor (GEM) Reports, related documents are available at: http://www.gemconsortium.org/;

http://www.babson.edu/Academics/centers/blank-center/global-research/gem/Pages/home.aspx; and https://entrepreneurship.bschool.cuhk.edu.hk/gem_hk.

Note 7. Excerpted from a Special Report: Entrepreneurship from The Economist. The Report was posted on $12^{\text {th }}$ March, 2009, and titled as Global Heroes, accessible at http://www.economist.com/node/13216025.

Note 8. Markets in China are barely fazed by scandal, unless the state is involved, posted at The Economist on August $20^{\text {th }}, 2011$ at: http://www.economist.com/node/21526407. A list of China Stock Scandals, posted at Euromonney, accessible at: http://www.euromoney.com/china-stock-scandals.html. Google search with a string of 'financial scandals in China' pops out 30,200,000 results in 0.44 seconds.

Note 9. Source: http://www.zerohedge.com/news/2015-11-03/over-40-chinese-goods-sold-online-are-counterfeit. Google search with a string of 'online counterfeit or fake products in China' pops out 1,280,000 results in 0.25 seconds. 
Note 10. An article by Eric Schurenberg, the Editor-in-Chief of the INC Magazine. The article was published on the $9^{\text {th }}$ of January of 2009, accessible http://www.inc.com/eric-schurenberg/the-best-definition-of-entepreneurship.html.

Note 11. https://en.wikipedia.org/wiki/EMPRETEC. Accessed on Dec. 22 $2^{\text {nd }}, 2016$.

Note 12. http://www.doingbusiness.org/rankings accessed on November $12^{\text {th }}, 2016$.

Note 13. Ibid

Note 14. Global Entrepreneurship Monitor (GEM) Reports, related documents are available at: http://www.gemconsortium.org/;

http:/www.babson.edu/Academics/centers/blank-center/global-research/gem/Pages/home.aspx; and https://entrepreneurship.bschool.cuhk.edu.hk/gem_hk.

Note 15. Accessible at http://www.kauffman.org/multimedia/infographics/2013/kiea-interactive.

Note 16. National Bureau of Statistics of China, http:/www.stats.gov.cn/english/. Accessed on Aug. $5,2016$.

Note 17. Ibid

Note 18. An interview with a senior economist and consultant for the central government, the interview was conducted on Novermber, $11^{\text {th }}, 2015$. 